Portland State University

PDXScholar

$11-7-1996$

\title{
Creating Collaborative Learning Environments: A Curriculum Proposal for Instructors
}

Carol Rae Chislett

Portland State University

Follow this and additional works at: https://pdxscholar.library.pdx.edu/open_access_etds

Part of the Educational Administration and Supervision Commons Let us know how access to this document benefits you.

\section{Recommended Citation}

Chislett, Carol Rae, "Creating Collaborative Learning Environments: A Curriculum Proposal for Instructors" (1996). Dissertations and Theses. Paper 5083.

https://doi.org/10.15760/etd.6959

This Thesis is brought to you for free and open access. It has been accepted for inclusion in Dissertations and Theses by an authorized administrator of PDXScholar. Please contact us if we can make this document more accessible: pdxscholar@pdx.edu. 
The abstract and thesis of Carol Rae Chislett for the Master of Science in Education: Educational Policy, Foundations, and Administrative Studies were presented November 7,1996 , and accepted by the thesis committee and the School.

COMMITTEE APPROVALS:

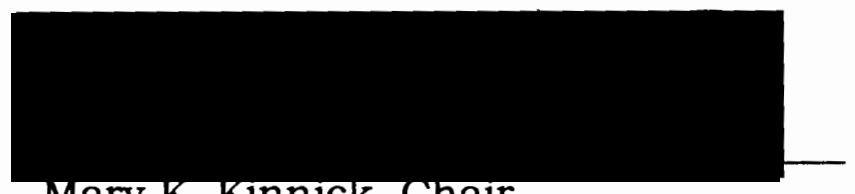
Mary K. Kinnick, Chair

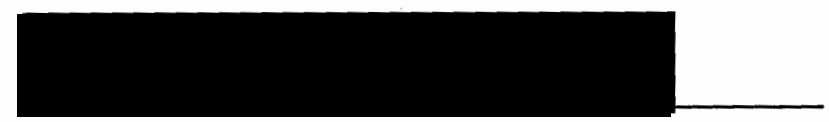

Dannelle D. Stevens

SCHOOL APPROVAL:

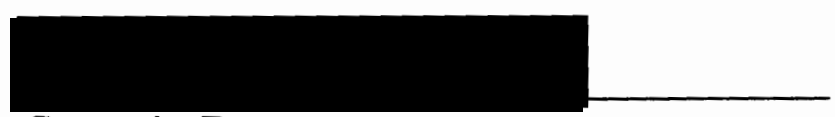

Scott A. Dawson

Representative of the Office of Graduate Studies

Robert B. Everhart, Dean

School of Education

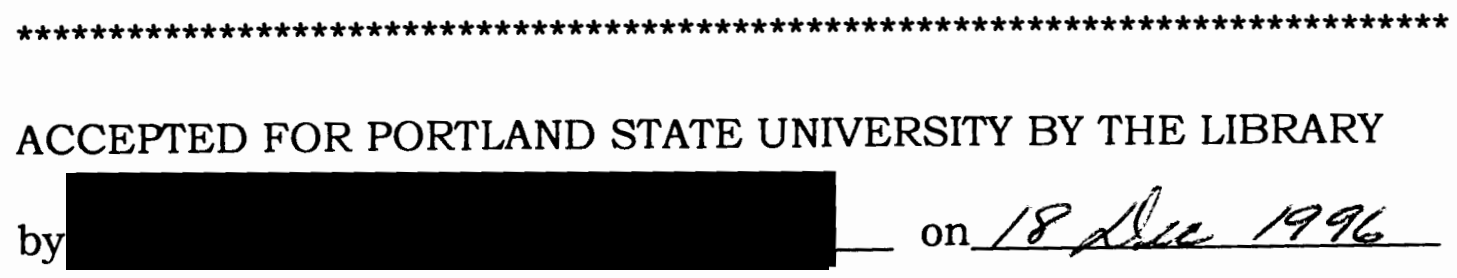




\begin{abstract}
An abstract of the thesis of Carol Rae Chislett for the Master of Science in Education: Educational Policy, Foundations, and Administrative Studies presented November 7, 1996.
\end{abstract}

Title: Creating Collaborative Learning Environments: A Curriculum Proposal for Instructors.

Groups of students or employees working together to solve problems, gain conceptual understanding, or create new approaches are expected to yield results significantly better than when working individually. Classroom collaboration leads to increased learning and retention, improved interpersonal skills, and enhanced appreciation for and commitment to the educationai process.

With the increased discussion of its benefits, there is more emphasis on including collaboration in the classroom. The challenge for today's faculty and students is to learn what their roles and expectations are in the successful collaborative environment.

The purpose of this study was to design a curriculum for instructors in techniques for creating collaborative environments. In 
addition to reviewing the current literature to learn about collaborative environments in the college classroom, instructors were interviewed to learn about their experiences and successes with collaborative learning. Information from the literature review and the faculty interviews were used to propose the curriculum.

Principles of collaborative learning evident through the literature and the interviews are that it requires trust, development of relationships, conversation, incorporating differences, the teacher as learner, and students be responsible for their own learning. The instructor must be able to create that environment by teaching social and collaborative skills, being willing to self-disclose, assessing where students are and by taking care of technical tasks such as preplanning, assigning students to groups, designing collaborative activities and evaluating results of the collaborative process, the group's product and the individual's contribution.

Caffarella's (1994) interactive model for program development provided the structure for the development of the curriculum. Through the application of the model, curriculum ideas were explored and narrowed into the development of the program objectives. Transfer of learning activities incorporated into the curriculum are reliant upon intense practice of collaborative skills throughout the course. The learning is experiential. 
The curriculum includes objectives, instructional plans, evaluation plan and questionnaire, and proposed assignments.

Proposed as a traditional ten-week course, it is intended as a generic example of the course format. Depending upon the context in which the course occurs and its audience, it may be formatted to fit a weekend workshop or other teacher oriented format. 
CREATING COLLABORATIVE LEARNING ENVIRONMENTS:

A CURRICULUM PROPOSAL FOR INSTRUCTORS

by

CAROL RAE CHISLETT

A thesis submitted in partial fulfillment of the requirements for the degree of

\author{
MASTER OF SCIENCE \\ in \\ EDUCATION: \\ EDUCATIONAL POLICY, FOUNDATIONS, \\ AND ADMINISTRATIVE STUDIES
}

Portland State University

1996 


\section{ACKNOWLEDGMENTS}

The inspiration for this thesis came from the wonderful collaborative experiences I have had during my master's work at Portland State University. I especially have been inspired by the enthusiastic women students I have come to know, respect and appreciate, who indomitably sought new and invigorating experiences, regardless of age or circumstances. In particular, I remember Heidi Stotlz with whom I collaborated on several projects, and Anne Bachman, now in Korea teaching English.

Many thanks to the faculty who generously shared their time with me for the interviews which provided such richness and helped me better envision the curriculum proposed here. And, special thanks to Mary Kinnick, who said the right things at the right time and suggested this idea in the first place.

Additionally, I am eternally grateful for my patient and stimulating friends who supported and listened to me as I agonized through the development of this thesis. They are among the finest folks to populate the planet and include Carmel Bentley, Carol Trumbauer, Casey Laguardia, and my wonderful sons, Jason Jones 
and Tivon Abel. Lastly, though first in my heart, my thanks go to my mother, Lois Chislett, another inspiring woman. 
TABLE OF CONTENTS

PAGE

ACKNOWLEDGMENTS $\ldots \ldots \ldots \ldots \ldots \ldots \ldots \ldots \ldots \ldots$ ii

LIST OF TABLES $\ldots \ldots \ldots \ldots \ldots \ldots \ldots \ldots \ldots \ldots \ldots \ldots \ldots \ldots \ldots$ vii

CHAPTER

I INTRODUCTION $\ldots \ldots \ldots \ldots \ldots \ldots \ldots \ldots \ldots$

Purpose of the Study .............. 3

Author's Background and Interests . . . . . . 4

The Framework of the Thesis . . . . . . . . 6

II REVIEW OF THE LITERATURE $\ldots \ldots \ldots \ldots \ldots \ldots$

Exploring the Concept of Collaborative Learning. 8

Defining Collaborative Learning . . . . . . . . 9

Benefits of Collaboration ........... 15

Change in the Instructor's Role $\ldots \ldots \ldots \ldots 20$

Change in the Students' Role . . . . . . . 26

Elements for Collaborative Learning Successes. . 31

Preparing the Students

Structuring Collaboration

The Collaborative Process

Evaluating Collaborative Efforts 
Cultural Differences in the Collaborative

Environment ..............

Cultural Difference

Value of Diversity in Collaborative

Environments

Cultural Clash

Awareness

Summary $\ldots \ldots \ldots \ldots \ldots \ldots$

III $\quad$ PROCEDURES $\ldots \ldots \ldots \ldots \ldots \ldots \ldots \ldots$

Curriculum Development Methods . . . . . 58

Contributing Faculty

The Interview

Procedures

IV $\quad \operatorname{RESULTS} \ldots \ldots \ldots \ldots \ldots \ldots \ldots \ldots \ldots$

Creating the Curriculum $\ldots \ldots \ldots \ldots \ldots 6$

Establishing a Basis for the Planning Process . 66

Gaining Faculty Support

Context of the Planning

Identifying and Selecting Program Ideas . . . . 69

Curriculum Ideas from Faculty Interviews Selecting Curriculum Ideas

Limitations of Collaborative Learning . . . . . 83

Program Objectives ........... 86

Transfer of Learning . . . . . . . . . . 88

Evaluating Effectiveness . . . . . . . . . . 90

Instructional Plans $\ldots \ldots \ldots \ldots \ldots$. 91 
V DISCUSSION OF THE PROPOSED CURRICULUM . . . 93

Course Proposal ............... 93

Instructional Plans . . . . . . . . . . . . 94

Evaluation Methods $\ldots \ldots \ldots \ldots 9$

Collaborative Groups . . . . . . . . . . 97

Conclusion $\ldots \ldots \ldots \ldots \ldots \ldots$

REFERENCES ......................... 99

APPENDICES

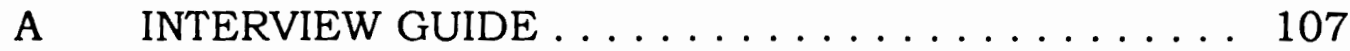

B PARTICIPANT COURSE EVALUATION

QUESTIONNAIRE (DRAFT) . . . . . . . . . 110

C COURSE PROPOSAL ............... 113

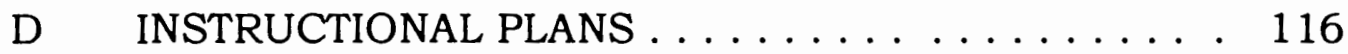




\section{LIST OF TABLES}

TABLE

PAGE

1. Implications from the Literature for Inclusion in the Curriculum ................ 57

2. Caffarella's Interactive Program Development Model 61

3. Faculty Suggestions for Curriculum Ideas . . . . . 76

4. Characteristics of Collaborative Learning Environments: Implications from Faculty Interviews and the Literature for Inclusion in the Curriculum. . . . . 81

5. Curriculum Objectives and Prinicples ........ 82 
CHAPTER I

\section{INTRODUCTION}

Collaboration, working together to develop knowledge, investigate questions and explore, develop and pose answers, both in education and in the work place is all the rage. Groups of students or employees working together to solve problems, gain conceptual understanding, or create new approaches are expected, according to its advocates, to yield results significantly better than when working individually (Slavin, 1983; Johnson \& Johnson, 1984; Cohen, 1986; Qin, Johnson, \& Johnson, 1995). Within the educational arena, collaboration leads to increased learning and retention, improved interpersonal skills, and enhanced appreciation for and commitment to the educational process (Johnson, Maruyama, Johnson, Nelson, \& Skon, 1981; Cohen, 1986). In addition, it provides valuable preparation for the team work expected in the workplace. Unfortunately, many colleges do not teach in ways which cultivate collaborative skills.

Teachers teach as they were taught, and the predominant method for many decades has been the lecture format. Students also 
are accustomed to this format and have grown to expect it in the classroom. Many, particularly the traditional college students (18 to 21 year olds), have adopted a passivity toward the education, and expect the instructor to fill them up. They feel that the instructor is shirking the teaching responsibility when attempts are made to actively involve students in the learning process (Cohen, 1986; Finkel \& Monk, 1992). The teachers' lack of skill in creating collaborative environments and the students' passive resistance to participating have combined to limit collaboration in the college classroom.

Increasingly, however, there is a push for collaboration. The wave of team work activities within the work place has contributed to this push. Businesses want employees who know how to solve problems together; the traditional competitive college environment is not preparing students for the needs of these businesses (Cohen, 1986). Additionally, there is increasing evidence that learning improves through group activities and an increased focus on the importance of interpersonal relationships to learning and to problem solving (Hall, 1971; Cohen, 1986; Liden, Wayne, \& Bradway, 1996).

The challenge for today's faculty and students is to learn what their roles and expectations are in the successful collaborative environment. 
Purpose of the Study

The purpose of this study is to design a curriculum for instructors in techniques for creating collaborative environments within the classroom.

In addition to reviewing the current literature to learn about collaborative environments in the college classroom, instructors will be interviewed to learn about current practices in collaborative learning. Information from the literature review and faculty interviews will be used to propose a curriculum. Key questions which will be posed to those interviewed include: What are your experiences with collaborative learning? What are the characteristics of an effective collaborative learning environment? What challenges have you faced in creating collaborative learning experiences and how have you dealt with them? What are the skills you believe are essential for instructors creating collaborative environments? In what way have cultural differences within groups impacted the creation of the collaborative environment? And, how have you factored these differences into your collaborative efforts? What advice would you give to other faculty interested in using collabortive learning in the classroom? 
Author's Background and Interests

Following twenty years experience in the business world, I rekindled my interests in doing graduate work in education. Among the faculty I encountered, instructional styles varied. Some followed the traditional lecture format; others used a blend of small group discussion and lecture; several others used a collaborative approach. Initially, I was uncomfortable with the collaborative approach. Returning to the college arena after twenty years, I was uncertain about my 'place' in the educational environment; collaboration made me nervous.

It was not long, however, before the rewards I received in the collaborative classes exceeded those received in the traditional classes. I began to make the connection between the collaborative teams with which I had worked in business and government and the classes using this style. I discovered that the quality of the product, the merits of solutions achieved in the collaborative groups were greater. The process of arriving at solutions was significantly more rewarding in the collaborative groups because of the trust and relationship building which occurred along with the solution development. These groups were exciting and invigorating. 
I compared the classes and work groups which did not use collaboration to those that did. My belief in the quality of the product was absent from those without collaboration. Regard for the others in the group was likewise absent, either because the opportunity to develop relationships had not existed or because the trust did not develop. They were not fun. I wanted to make them collaborative.

Soon, I questioned why more faculty did not incorporate elements of collaboration into their classes. I began examining the work groups I participated in which did not. It seemed to me that in both cases, there was an inability on the part of the 'leader' to relinquish authority. Some expressed the belief in participatory decision-making or collaborative learning but seemed not to have developed the techniques to put that belief into practice.

I found that I wanted a way to convince faculty to teach more collaboratively, just as I wanted a way to convince managers to make decisions more collaboratively. As I read about collaboration I became convinced that without more training in collaborative techniques and without guidance in the different role expectations for collaborative leaders, collaborative practitioners would continue to be few.

Focusing my thesis on this topic was a natural outcome of the continuing interest I have in collaboration. The process of researching and writing this thesis is cathartic in that I have learned more about 
the practice of collaboration and reinforced my belief in its value within both education and business.

\section{The Framework of the Thesis}

Chapter I of this thesis introduces the concept of collaborative learning, provides a statement of the problem and the purpose of the thesis. Chapter II reviews relevant literature in five areas: defining collaborative learning and describing its benefits; exploring changes in the instructor's role when developing collaborative environments; considering changes in the students' role within a collaborative environment; discussing key skills and techniques in creating collaboration; and addressing issues of diversity in the collaborative environment. Chapter III presents the methods to be used in the curriculum design which will include one on one interviews with selected instructors. Results from the interviews, coupled with research information, will serve as the basis for defining the elements essential for the collaborative learning curriculum. How the instructors are selected and interviewed, what questions are asked and how the results are evaluated will be addressed in this chapter as will the approach used to develop the curriculum. Chapter IV details the curriculum development process and the interview results. 
Chapter V, then finally describes aspects of the proposed curriculum which is included in Appendix C. 


\section{CHAPTER II}

\section{REVIEW OF THE LITERATURE}

Exploring the Concept of Collaborative Learning

The purpose of this thesis is to create a curriculum or guide for instructors seeking ways to effectively create collaborative environments. First, however, questions about what collaborative learning is and the benefits of learning through collaboration are considered. The first and second sections of this chapter provide the foundation by responding to these questions. Relevant literature on collaborative learning is discussed. Collaborative learning significantly differs from the traditional lecture format of the college classroom. Consequently, the new role of the instructor in a collaborative classroom is explored in the third section of this chapter. Next, attention to the changed role for the student is considered. Then, techniques or elements critical to collaborative learning identified in the current literature are presented. And lastly, the challenges of diversity and difference within collaborative environments are discussed. 
Defining Collaborative Learning

Most dictionaries define collaboration as working together. A brief synthesis of descriptions in the literature is that collaborative learning is a process of working together to learn and explore concepts and meanings related to a body of knowledge, or to develop solutions to complex multifaceted problems. But, collaborative learning or working together means more than merely solving problems or developing knowledge.

Within the educational environment, there are a number of techniques which may be considered "working together." Cooperative learning, collaborative learning, learning groups, discussion groups are all methods of working together. What makes them different and do these differences inform this thesis?

Bruffee (1995) correlates cooperative learning and collaborative learning by stating, "In both we learn to share our toys and we learn by sharing them" (p. 18). The major distinction he articulates is that collaborative learning lacks the accountability implicit in cooperative learning while cooperative learning replicates the authority relationships of the traditional classroom.

In an earlier work, Bruffee (1993) makes a distinction between cooperative learning and collaborative based upon "foundational and 
non-foundational knowledge" (p. 9). Foundational knowledge is that for which there are generally accepted "right answers;" whereas, nonfoundational knowledge is constructed and maintained by "negotiating with one another in communities of knowledgeable peers" (Bruffee, 1993, p. 9). He equates cooperative learning with foundational knowledge acquisition and collaborative learning with the development and creation of non-foundational knowledge. According to Bruffee, learning is an interdependent, social process occurring among people as opposed to between people and things. Following this thinking, learning is dependent upon the interaction and joint contribution of a group of learners. He specifically defines collaborative learning as that in which

students work on focused but open-ended tasks. They discuss issues in small consensus groups, plan and carry out long-term projects in research teams, tutor one another, analyze and work problems together, puzzle out difficult lab instructions together, read aloud to one another what they have written, and help one another edit and revise research reports and term papers. ( p. 1)

Bruffee's (1993) definition of collaborative learning can be contrasted with the concept of cooperative learning described by Cooper and Mueck (1992) who distinguish cooperative learning from other team learning techniques (including collaborative) by accentuating its focus on positive interdependence and individual accountability. Positive interdependence involves group members 
working to make sure all group members have the knowledge and understanding. On the other hand, individual accountability means that each member is responsible for demonstrating the knowledge. It is "an instructional strategy in which small groups work toward a common goal" (Cooper \& Mueck, 1992, p. 68). According to them, team learning which does not accentuate positive interdependence and individual accountability may be called collaborative learning, but not cooperative learning. Cooperative learning, according to them, also necessitates care in the assignment of members to groups, the instructor in the role of facilitator and attention to social skills. It is "face-to-face verbal problem solving" (Cooper \& Mueck, 1992, p. 69). Smith and MacGregor (1992) define cooperative learning as the most structured form of team learning requiring clearly defined tasks and close monitoring by the instructor. The broader concept of collaborative learning, according to them, depends upon an active, social, "talk to learn" process in rich contexts involving students with diverse backgrounds and prior knowledge. Face-to-face talking seems to be essential whether called cooperative or collaborative learning.

Goodsell, Maher, and Tinto (1992) define collaborative learning as a classroom technique which "changes students from passive recipients of information given by an expert teacher to active agents in the construction of knowledge" (p. 4). 
Bosworth (1994) states that "collaboration involves cooperation and compromise, flexibility in roles, trust and respect for others, question as well as criticism and group problem solving" (p. 26). Bosworth excludes competition in his concept of collaboration and emphasizes consensus. In contrast, Bruffee (1995) claims that consensus is not essential to the collaborative process. Christensen (1991a) discusses learning communities as a form of collaborative learning with the definition that in a "true learning community, diverse backgrounds blend and individuals bond into an association dedicated to collective as well as personal learning" (p. 19). They agree with others that the process of team learning is a partnership.

Tiberius and Billson (1991) discuss two metaphors of teaching; the one in which the teacher dispenses the information and the other, the metaphor of conversation. In the conversation metaphor, the teacher guides the student and is "a learner in the process" (p. 68). The interactive nature of collaborative learning, say Tiberius and Billson, necessitates effective communication and relationship building. It is a social act involving the learners in sharing their own views and ideas, based upon the knowledge they bring to the group, and thereby expanding and building upon these ideas through the mingling of the multiple and diverse backgrounds shared. It is the construction of knowledge. "It should teach students to build a bridge 
from what they know to discover that which they do not know" (Haring-Smith, 1995, p. 338).

Cohen (1986) uses the broad term of group work which is defined as "students working together in a group small enough so that everyone can participate on a task that has been clearly assigned" ( $p$. 1). Group work, according to Cohen, requires that there be no direct or immediate supervision by the teacher and that members need each other to some degree to complete the task. The absence of direct guidance from the teacher brings Cohen's concept closer to that described by Bruffee $(1993,1995)$ rather than the cooperative groups of Cooper and Mueck (1992).

Collaborative learning engages students in working with concepts and applying knowledge in functional ways. It seeks to activate students in the development of their own knowledge rather than having them be passive recipients of knowledge conveyed by the professorial talking head. Collaborative learning is the antithesis of the foundational post-Cartesian point of view in which "knowledge is a kind of substance contained in and given form by the vessel we call the mind" (Bruffee, 1993, p. 129). In collaboration, instead of pouring the knowledge from the full teacher to the empty student, students bring their own full vessel and mingle their current knowledge with that of the other students to build new forms. 
Whether called collaborative or cooperative, the learning technique centers on students' processes of investigation, discovery and application. It does not depend upon the instructor dispensing knowledge. Most references to collaborative learning draw no distinctions between cooperative and collaborative. Although the terms seem to be used interchangeably, perhaps the clearest distinction is that described by Bruffee (1993), between foundational and nonfoundational and as a consequence, perhaps cooperative learning is a technique more applicable to the primary grades while collaborative learning may be a more viable technique for the college level student. Critical to either, however, is that they encourage and allow students to remember, bring forward, and value knowledge they already have. For purposes of this thesis, I have chosen to emphasize the term "collaborative" rather than "cooperative." But, following Smith and MacGregor's (1992) lead, the term is used broadly and intended to encompass team learning activities in the college classroom which engage the student in the development of knowledge through interacting as a part of a group to investigate questions and explore, develop and pose answers. The instructor, in the collaborative environments I envision, facilitates the students in their discovery process and contributes to evaluation of their success both as a team and as individuals. 
Benefits of Collaboration

Collaboration reaps benefits for students in multiple ways. Through increasing opportunities for conversation, it can expand knowledge. Through collaborative approaches, students can advance abilities to question, research and problem solve. Collaboration can also increase levels of achievement, both for the group of collaborators and for the individual. Students take a more active role in their educational process through collaboration.

Conversation is the keystone to the collaborative process. Bruffee (1993) quotes Uri Treisman in emphasizing its importance: "conversation is of such vital importance to learning that, with it, any of us has a shot at doing whatever we want to do. Without it, none of us stands a chance" (p. 26). Any of us who has had collaborative experiences, in the classroom or in the work place, appreciates the building block nature of conversation and its value to the problem solving process. A thought expressed by one team member triggers a thought by another; when woven together, collaboratively generated ideas provide better solutions than those developed individually. Or, as Bruffee (1995) states, "Two or more students working together may learn more than individual students working alone: two heads are better than one" (p. 12). 
In the safety of the collaborative environment, students can voice concepts and ideas which may not be fully formed and work through concepts by talking with others. Through team conversations, members can work out assumptions and discard biases. This form of "descriptive feedback...occurs in the course of interaction between teachers and students" (Tiberius \& Billson, 1991, p. 75) and enhances learning.

Adler (1982) discusses this principle as well in the Paideia Proposal, "The more there is questioning and discussion, the more enlivened the class hour and the better the understanding of the subject being taught." In a discussion with Freire, Macedo (Freire $\&$ Macedo, 1995) said, "it is important to create pedagogical structures that foster critical engagement as the only way for the students to come to voice" (p. 384).

Through the collaborative approach, students advance their abilities to question, search and obtain understanding. Perhaps even more importantly, according to Katz and Henry (1988), they learn "reflection and self-expression, and imagining, hypothesizing, interpreting and reality-testing [of] their ideas and those of others" (p. 157). While they are actively engaged in researching and problem solving in the content area, they are also acquiring and improving skills in inquiry, interaction, conflict resolution, and compromise. 
These skills are needed by the ideal MBA more than the technical skills related to the specific business, according to a national survey conducted by DuBois (1992).

Johnson and Johnson (1979, 1983, 1984, 1986, 1987a, 1987b, 1989,1990 ) and various of their co-collaborators (Johnson, Johnson, \& Skon, 1979; Johnson, Johnson, \& Smith, 1991; Johnson, Maruyama, Johnson, Nelson, \& Skon, 1981; Qin, Johnson, \& Johnson, 1995) have done extensive research into the achievement results of cooperative versus competitive approaches to learning. In one study, they indicate that cooperative efforts "result in more frequent use of higher-level reasoning strategies, more frequent process gain and collective induction, and higher performance on subsequent tests taken individually" (Johnson \& Johnson, 1990, p. 33). They postulate that cooperative learning may improve problemsolving success because of the interaction, feedback, inquiry and generation of alternatives, and development of shared results (Qin, Johnson, \& Johnson, 1995). They believe that the skills for cooperative learning help students to be successful in all phases of their lives because cooperation is critical in families, businesses, communities and friendships.

Johnson and Johnson's (1986) conclusion that interdependence is critical to success in cooperative work groups can be confirmed in 
the business environment. In a study of work groups within multinational corporations, Liden, Wayne, and Bradway (1996) found that when work group members must interact and depend on each other to complete the work, performance results were improved. The importance of collaboration and conversation is demonstrated in a research study by Frierson (1986). Frierson's study, conducted with baccalaureate nurses following the completion of course work, measured the effects of two interventions prior to taking the State Board Examination. Significantly higher results on this exam were experienced by the group who received test-taking instruction and learning team methods than by both the control group and the group receiving test-taking instruction only. The team learning techniques included team building and consensus development.

Because students are actively working with concepts and principles in the course of collaboration, learning is less transient than that gained through the traditional lecture format. In the traditional approach, students faced the problem of assimilating knowledge independent of its use. The lecture format defies the real aim in education. "...True education requires students to be personally invested in the learning process. And that will occur...only when 
students have had a hand in shaping the content, direction and pacing of classes" (Garvin, 1991, p. 5).

Lazarowitz and Karsenty (1990) credit collaborative learning with higher levels of achievement and self-esteem "...resulting from greater student involvement in learning, a heightened sense of personal responsibility for learning" (p. 124). The importance of the student's personal investment into the learning process is surely one of the strongest supports to collaboration's success as an approach to student achievement.

For all the literature about the value of collaborative learning, instructors continue to resist creating collaborative environments (Cohen, 1986; Romer \& Whipple, 1991; Bruffee, 1993; Gerlach, 1994). Many view collaborative learning as a time distractor when there is so much content to convey. Others continue to teach as they were taught. In a practical study, Lowry, Osman-Jouchouz, and Cyr (1994) state that teachers "had never formally been taught how to do [collaboration] effectively" (p. 506), but had been told that it was an important teaching method. Nevertheless, the research provides persuasive evidence that collaborative learning increases inquiry, higher level reasoning, critical thinking and inspires students' personal investment in their own learning (Johnson \& Johnson, 1984, 1989; Nelson, 1994; Qin, Johnson, \& Johnson, 1995). 
Change in the Instructor's Role

Teachers have been accustomed to teaching as they were taught and generally, that means they face the challenge of change when attempting to incorporate collaboration into their repertoire.

Significantly different skills are practiced when creating collaborative learning environments. Traditional lecture instruction required instructors to prepare detailed outlines and to practice stimulating ways of communicating a set body of knowledge. Focus was on knowledge of content almost exclusively and to a lesser extent the performance aspects of presenting an engaging lecture. Collaboration, on the other hand, requires no less preparation, but is focused on planning the group work and anticipating the group dynamics.

Much of the writing on collaboration for college instructors focuses on how it works and how it can be used in the classroom. There is very little literature to help instructors understand how their role is different in a collaborative environment and to guide them in creating collaboration. According to many (Sheridan, Byrne, \& Quina, 1989; Finkel \& Monk, 1992; Smith \& MacGregor, 1992; Gerlach, 1994) and based upon my experiences as a graduate student, most instructors are skeptical, if not out right negative, about collaborative learning and fail, consequently, to see a place for it in their courses. 
Gerlach (1994) found that "they often lack either the confidence or the knowledge needed to experiment with collaborative learning activities in their classrooms" (p. 6). Instructors can acquire the confidence to create collaborative learning experiences through understanding and practicing the different roles required of them in collaboration.

Creating collaborative environments moves the instructor away from the talking head concept and toward a role more like that of a coach in which learning is facilitated. Cohen (1986) discussed this shift in the teacher's role away from the classroom authority. According to Cohen, teachers in collaborative environments focus on designing the tasks, assigning students to groups and communicating rules and then holding the students accountable for the products.

The instructor guides the group toward interdependence and helps create the trusting environment which is essential to effective collaboration (Tiberius \& Billson, 1991). Freire (Freire \& Macedo, 1995) puts it this way

A better way to proceed is to assume the authority as a teacher whose direction of education includes helping learners get involved in planning education, helping them create the critical capacity to consider and participate in the direction and dreams of education, rather than merely following blindly. (p. 379)

The instructor involved with collaborative learning activities moves from being the dispenser of knowledge to being a facilitator, or 
as Gerlach says, "managerial role." The managerial responsibilities include setting time limits, organizing the room to accommodate the groups, assigning students to groups, assuring they are on task and facilitating the group's reporting out upon task completion. Tiberius and Billson (1991), Wiener (1986), and Bruffee (1993) likewise discuss the managerial functions of dividing the students into groups, designing and assigning tasks and evaluating the quality of work.

Although it may seem that the role change from lecturer to creator of collaborative environments causes the instructor to relinquish authority, instructors continue to have the primary role for designing and organizing the learning opportunities. The move is away from a teacher-centered environment in which instructors are the authority and the experts to one that is student-centered. Finkel and Monk (1992) describe the burden instructors assume for the entire learning process as the "Atlas complex." Freeing themselves from this complex to create a student-centered learning model is no easy feat. Finkel and Monk suggest identifying teaching functions such as those performed in preparation for the class of "interpreting student misconceptions, setting goals and tasks, and analyzing his subject matter" (p. 54) and those inside the class "listening to students, redirecting them, clearing up misunderstandings, and supporting students" (p. 55). Focusing on these, rather than teaching roles, can 
free the instructor by allowing the distribution of these functions and results in sharing the responsibility for learning with the students.

All seven principles of the effective teacher identified by Chickering and Gamson (1991) can be actualized in the collaborative environment. The shift to a collaborative environment from a lecture format particularly expresses the principle of encouraging contacts between students and instructors, and among students. The collaborative environment is dependent upon developing these relationships. Tiberius and Billson (1991) claim that an instructor "who does not learn students' names, who is insensitive to their feelings and opinions or their problems in dealing with the course, or who ignores signs of low morale is performing inadequately" (p. 78). Instructors must focus on developing relationships with and among students which will encourage open two-way communication. Communication must be aimed at forming stable relationships with students to contribute to and build effective collaborative environments. The instructors must be more than authorities in the learning process; instructor-student, student-student partnerships must be developed.

A real key to creating collaborative environments is the social ability of the students to interact in productive ways. This is a different set of skills than those involved with dispensing knowledge 
through lectures. Consequently, instructors must teach social skills and develop within the students the ability to work effectively together (Cohen, 1986; Gerlach, 1994; Lowry, Osman-Jouchouz, \& Cyr, 1994; Lyman, 1995). As a part of developing and modeling social skills, instructors must also emphasize courtesy and respect and instill the courage to take risks and appreciate diversity among students (Christensen, Garvin, \& Sweet, 1991). Trust and safety in the classroom become essential as students develop the skills to work together.

The instructor as an effective creator of collaborative environments "helps students develop the ability to interact socially over complex, intellectually demanding issues, thus integrating social and intellectual maturity" (Bruffee, 1993, p. 189). There is almost an art to defining goals for collaboration around which students can coalesce and enthusiastically invest their learning energies. Bruffee believes that through collaboration, instructors help students become members of a knowledge community and through this to achieve "what Dewey calls the ideal aim of education: the 'power of self control' as they develop the ability and confidence to exercise the craft of interdependence” (p. 3).

The shift to collaborative learning means that instructors must now "focus equally on classroom climate, group process, and the 
needs, interests and backgrounds of students" (Garvin, 1991, p. 6). Further, according to Garvin, there are three fundamental shifts which must occur. The collaborative process is more democratic; attention to the learning climate is critical; and questioning, listening and responding replace declarative explanation. Interpersonal skills provide the foundation for the shift to effective collaborative learning. Preparation for collaboration may initially seem to consume more time for instructors than the lecture format. And surely, as instructors begin to practice collaborative learning, preparation time will be significant. Not only must content be considered, but the importance of creating the group dynamics leading to effective collaboration must be attended to. Bruffee (1993) states that instructors must have knowledge of group dynamics, be sensitive to the social situation and relationships, have a better than average knowledge of the content and have the self control necessary to let the group work develop its own life. Katz and Henry (1988) accentuated the importance of understanding the present level of knowledge and development of students when creating activities. Preparation involves learning about the students in order to factor in that knowledge when designing the collaborative activities or determining how to group students for activities. 
Instructors creating collaborative environments are dependent on listening skills to be successful. Christensen et al. (1991) believe that questioning, listening and paying attention to dialogue and discussions are crucial tasks of the instructor which help students to relate. Additionally, instructors must be tuned to the non-verbal messages conveyed by students. They must be keyed to pick up on any indication that group work is going awry in order to resolve conflicts or make changes in group assignments or otherwise intercede.

Collaborative learning environments require instructors to acquire a whole cadre of new skills, or at least to apply skills in the classroom which when using the lecture method they did not need to consider. The social dynamics and the importance of teaching social skills, the managerial functions of organizing and keeping things on track, the conflict resolution and listening to both verbal and nonverbal communication are new challenges for instructors desiring to create collaborative environments.

Change in the Students' Role

Just as the instructors must learn new ways of teaching, so too must students learn new ways of behaving in the collaborative classroom. Many students are baffled by collaborative learning. They, 
together with many of their instructors, have been conditioned to expect that in the classroom, the instructor holds all the knowledge and it is to the instructor they turn for all the answers. Students adopt a passive approach to education and their own learning. For collaborative learning to be effective, the role of the student must change together with that of the instructor. As Svinicki (1991) put it, "learners are not simply passive recipients of information; they actively construct their own understanding. The learner is at center stage" (p. 27). What they learn and retain depends more on who they are and where they have been than on what knowledge instructors dispense.

Effective collaboration requires three significant changes in the students' role. The first is overcoming the resistance to working with other students to develop knowledge. Secondly, students are called to develop relationships and alliances, not usually a part of the typical college class. And, third, though not the least important, they must truly accept personal responsibility for their own learning.

The resistance students have to collaboration is in part a consequence of their belief in the unquestioned authority of the teacher. The challenge for students is to learn to be constructors of their own knowledge, to actively participate. Brilhart and Galanes (1995) believe that not all students come prepared to work in groups and would benefit from training in group work and discussion 
techniques to overcome resistance. Bosworth (1994) states "once students know the rules or procedures for a particular skill, they can, with practice and feedback, develop competence and confidence in their ability to work collaboratively" (p. 30).

Smith and MacGregor (1992) and Bosworth (1994) recommend that students also learn how to inquire, seek clarification, probe, elicit views, build rapport, raise questions and carefully listen. These skills follow from the move away from passive recipient to active participant in the learning process. To reap the benefits of collaborative learning students need these skills.

Another role difference for the student in the collaborative environment is similar to that expected of instructors: an appreciation of the importance of relationships and alliances in learning. Interdependence is emphasized repeatedly in the literature as one of the critical skills which can be learned through collaboration and through which collaboration can be most successful. Bruffee (1993) claims that students must learn to grant authority to peers, to accept the authority given to them and to exercise that authority judiciously and helpfully in the interest of a peer. Christensen (1991b) also points out the importance of alliances, collegial sharing of power, accountability and tasks. 
Bosworth (1994) describes a taxonomy of collaborative skills students need, the first two of which pertain to the importance of the relationship. The first, the interpersonal, emphasizes congeniality, eye contact, listening and positive support. The second relates to group building and speaks to the role of the student in actively participating in the group. Gerlach (1994) refers to the socially and emotionally demanding aspects of collaborative learning activities as students interact with others to create knowledge and meaning.

Another major role change for students in the collaborative environment is taking responsibility for their own learning experiences. The principles mentioned above make it patently clear that students cannot expect to learn through passive absorption of knowledge dispensed by instructors. Christensen (1991a) put it this way:

in deepening their personal involvement, taking responsibility for the quality of the discussion and making an emotional investment in the out come of the course, students claim ownership of their own education. (p. 19)

Smith and MacGregor (1992) indicate that as students begin to see that they are not merely receivers of the knowledge of others, they will understand that they are "responsible creators of their own knowledge and meanings -- a change that is essential to life-long learning and true intellectual development" (p. 11). 
Principles of cognitive theory discussed by Svinicki (1991) amplify why collaboration is an effective learning method and accentuate the participatory role most advantageous for students. The first of these is that for information to be learned, it must be seen as important. In many collaborative activities, students define the questions to be pursued, based upon what is important to them in the area of study. Secondly, during learning, students act upon information to make it more meaningful. In collaboration, students are challenged to draw upon their prior knowledge, to interact with others and to discuss and explore information thereby making it more meaningful. The third principle is that for information to be stored in long-term memory, it is organized in relation to prior knowledge and understanding of the world. When information is processed and developed collaboratively, it is linked to prior understanding and more solidified in long-term memory. Knowledge acquired through collaboration tends to be remembered over time. The fourth principle is that students continually check understanding; this is the basis of collaboration, students refining and revising and working with the information. In collaboration, students actively work with the information, meeting the fifth principle which is that transfer of learning happens through multiple applications. The sixth principle is 
that students learn better when they are aware of the learning process and when they evaluate and monitor their learning strategies.

The principle role changes for students, as discussed, are to overcome the resistance to sharing authority with the instructor, appreciate the value relationships and alliances have for the learning process and grasp responsibility for being creators of their own knowledge.

Elements for Collaborative Learning Successes

Instructors and students face changing roles when entering the collaborative environment. Protests against collaborative learning as a pedagogical model are frequently based upon a lack of knowledge about it and what is required for success in both creating and working within the collaborative environment. In this section, four components of the collaborative learning experience will be discussed: preparing a group of students for collaboration in the classroom; how collaboration is best structured, both in terms of activities and group formation; considerations for the process; and evaluation of learning gained in collaboration. 


\section{Preparing the Students}

As previously discussed, students enter the classroom with different assumptions about and experiences with collaborating in the college classroom. They also enter the classroom with different backgrounds and personal histories. The instructor must consider these factors whenever greeting a new class of students. The implications for practice for the instructor, given the unique set of experiences and assumptions held by students, is that of learning about what those experiences and assumptions are and how they influence the student's approach to learning. Guidelines for developing alliances with students posed by Billson and Tiberius (1991) begin with building mutual respect between students and instructors. This is likewise a precursor to laying the ground work for effective collaboration.

Through exercises designed to learn about the students, the instructor can also learn about their previous experiences with collaborative groups. Bosworth (1994) emphasizes the importance of working with students to demonstrate and develop collaborative skills prior to initiating collaborative activities. Katz and Henry (1988) also point out the importance for instructors of exploring the "variety of cognitive patterns among their students..to understand better previous problems in communication" (p. 26). Understanding where students 
start from is critical in order for instructors to be able to build the bridge from their current knowledge to the knowledge inherent within the course (Bruffee, 1993).

As a part of or following initial activities to learn about students, instructors benefit from incorporating exercises that teach collaborative skills, as Cohen (1986) and Bosworth (1994) suggest. Cohen states that introducing collaborative skills to students assures they will listen carefully, explain to each other, and provide feedback. Additionally, "students need to understand your purposes in introducing small groups and why group work skills are important" (Cohen, 1986, p. 35). She suggests creating introductory exercises which emphasize the importance of givirig and helping, which are critical skills in effective cooperative tasks.

Cooper and Mueck (1992) also include in their requirements for cooperative learning that team building exercises be introduced to allow practice in group work. The added benefits for students and instructors to these activities are described by Lyman (1995) as helping students become acquainted with each other and the instructor, offering opportunities for instructors to observe interaction and determine strengths and weaknesses, focusing on topics covered in the course, and introducing opportunities for critical and creative thinking. Too frequently the complaint of instructors is that 
collaboration fails to be effective in their classrooms. Had they introduced collaboration, learned about their students and practiced collaborative skills prior to launching collaborative projects, collaborative experiences may have been more effective.

\section{Structuring Collaboration}

Some believe that to fully satisfy the definition of collaboration, the activities designed must meet specific criteria. Others do not narrow the choices as rigidly. Most, however, refer to the conditions articulated by Johnson and Johnson (1986). Groups will be more productive than individual efforts when, according to Johnson and Johnson, there is positive interdependence, considerable face to face interaction between group members, personal commitment to achieving the group's goals, frequent use of interpersonal and smallgroup skills and regular evaluation of progress as a group by its members.

Structurally, then, collaborative activities must be designed to insure that all group members contribute and look to each other for validation of the group's progress. Gaining commitment of all members to the goals is possible when activities are skeletally structured by the instructor with details remaining the responsibility of group members. The collaborative activity which lends itself to 
parceling components of the work and distributing them among members, who then individually report back or prepare a section of a report, defies the intention of collaboration and decreases the opportunity for interaction. A carefully structured activity will include all group members in working with principles and creating the knowledge through direct interaction rather than individual, isolated efforts.

Gerlach (1994) has identified six characteristic of collaborative learning activities. These characteristics fit within the context of Johnson and Johnson's conditions described above. The first is that there is time for group consensus to occur. To achieve consensus considerable time to discuss, reflect and consider ideas posed by all members is necessary. At the same time, as Whipple (1987) said collaboration is not groupthink! In fact, it is precisely through the sense of community produced by good collaboration that individuals become better able to respect the differences and diversities that make them unique. (p. 5)

Nevertheless, in collaborative learning ample time to process, discuss, and develop community is essential. (Not all collaborative environments, require consensus to be effective. The very process invites and respects differences among members which may not always be resolved.) 
The second of Gerlach's (1994) characteristics for collaborative learning activities is that it be a specific task with a defined time frame for completion. Gerlach believes, and presents as her third characteristic, that members negotiate their roles within the group rather than the instructor making those assignments. Fourth, while she encourages consensus between members, the activities must teach respect for individual diversity and divergent views. A fifth characteristic is that the activities involve collaboration between the instructor and the students once the groups have reached consensus and refined the project. And lastly, evaluating the collaborative process is a necessary element.

On the other hand, Bruffee (1995) identifies four factors which coincide with his concept of non-foundational collaborative knowledge development. These four demark his concept of collaborative learning: no role assignment, no teacher intervention, no teacher-led group process evaluation, and encouragement of dissent.

Wiener (1986) discusses the importance of preparing written instructions for collaborative activities for students. According to Wiener, these should include how to collaborate in the assignment, elements of the text, if applicable, and discussion questions. Additionally, he suggests that there be a limited number of questions and that they progress from easier to more complex. To enhance the 
collaborative environment, he states that questions should require "the kind of critical thinking that leads to sustained responses from students at work in their groups" (p. 56).

Fiechtner and Davis (1992) conducted a survey of students to determine what worked for them in collaborative environments and what did not. They had heard students express the feeling that in groups, their work and grade were dependent upon others who may not make the investment they do. Through the survey, they learned that activities which involve both in class time and out of class time are more positively perceived.

Learning to develop effective collaborative projects takes time and practice. As MacGregor (1992) puts it, "the richest guides for teachers are their own experiments with teaching, the advice and experience of colleagues, and most importantly, formal and informal feed back from the students themselves" (p. 39). Hamilton (1994) reiterates this concept

Learning how to give students sufficient structure to explore ideas collaboratively without restraining their opportunities to contribute their own voices and knowledge to a new and unpredictable construction of understanding takes time and experimentation on the part of students and instructors alike. (p. 98)

How students are assigned to collaborative groups within the classroom can be the difference between a successful collaboration 
and an unsuccessful one. Fiechtner and Davis (1992) surveyed students and learned that their perception of the most successful collaborative experiences where those in which the instructor assigned students to groups rather than when they self-selected. This finding is supported by Johnson, Johnson, and Smith (1991) who recommend that the instructor make the assignments or that students be randomly assigned as in the count off from one to five or whatever the total number of groups expected. Cooper and Mueck (1992) support the instructor assigned approach.

Research indicates that heterogenous groups are the most effective (Miller \& Harrington, 1990; Johnson, Johnson, \& Smith, 1991). With the instructor responsible for group assignment, achieving heterogeneity is more likely. Haring-Smith (1993) has found that the heterogenous group which blends students with different backgrounds and strengths will be the most successful. Cooper and Mueck (1992) likewise contend that heterogenous groups are more effective. Miller, Trimbur, and Wilkes (1994) suggest approaches to heterogeneity through the use of various inventories such as the Myers-Briggs, learning style inventories, and the cognitive styles model. Miller and Harrington (1990) explore issues of heterogeneity within groups based upon ethnicity and pose that there may be times when homogeneity will be more successful (later in this chapter issues 
of cultural and ethnic differences within collaborative groups will be discussed more fully).

There is little dispute among education professionals that the optimum group size is between four and seven. With some activities, groups will initially be pairs, but later join other pairs; the intent of the activity will influence the size. Peer writing may need to be pairs, while activities with the goal of exploring the social implications of political action are more effective with four, five or more.

To attain the personal responsibility mentioned by Johnson and Johnson (1986) and the sense of community described by Whipple (1987), group composition should remain consistent through the course. Fiechtner and Davis (1992), in their survey of students found that students ranked their most successful experiences as those in which group assignment continued through the course. Although, introductory exercises, used to lay the groundwork for collaboration and to acquaint the instructor with students and their unique qualities, may involve different group combinations, once the groundwork is laid and students are actively working on projects, group composition is best when constant through the course.

Collaboration, as has been shown, involves heterogeneously assigned groups of four to seven over a length of time, actively engaged 
in creating knowledge through commitment to the goals, interaction and interdependence of members.

\section{The Collaborative Process}

Once groups are formed and charged with researching answers to problems, the instructor then moves to the role of monitor and observer. Specific ethical behavior expected of the group members may be observed and reinforced if need be. These behaviors are identified by Brilhart and Galanes (1995) as the willingness to share one's views and encourage others to do likewise, practicing honesty and integrity which places focuses on the goals of the group and may supersede the individual, respecting other team members in words and actions, and making the effort to make relevant contributions and be aware and curb expression of one's own prejudices and predispositions.

Hertz-Lazarowitz and Shachar (1990) evaluated the verbal messages of teachers in cooperative learning compared to the verbal messages in the more traditional whole-class instruction. According the them:

The most fascinating finding is that when the teacher encounters a set of small systems instead of the whole class, he radically increases positive pro-social instructional behavior and drastically decreases negative instructional behaviors such as disciplining, interrupting 
pupils verbalizations and hurrying them when they work. (p. 88)

Although this research was based upon the $\mathrm{K}-12$ classroom, it is reasonable to suppose that verbal messages at the college level will be focused on engaging students to actively interact with the concepts and the other students.

While observing groups in action during in-class collaborative time, instructors guide students in the use of collaborative skills and make suggestions for possible new directions. Modeling the skills expected of students demonstrates the commitment to collaboration. Downs, Javidi, and Nussbaum (1988) emphasize the use of humor, self-disclosure and narratives as qualities of effective instructors. Modeling these for students contributes to the development of community within the groups and bridges the gap between instructors and students. Further, Whipple (1987) indicates that in collaboration, instructors and students are active participants, which humor, selfdisclosure and the use of narrative will reinforce.

A careful balance must be achieved between the instructor's participation with and guidance of collaborative groups and the instructor's authority for the knowledge. Wiener (1986) said, "Usually, collaboration advances best when groups are left pretty much to the students themselves” (p. 58). He adds that the instructor may appear 
not to be involved in the learning process, even though this apparent laissez-fair approach may be an important contribution to their learning.

Watching for excessive conflict and being responsive to those few groups who may not be fully functioning are the instructor's tasks while collaborative groups are in action. Students practice leadership, shared decision-making, trust, effective communication and conflict management. Everyone works on the skills needed to work together. Everyone creates knowledge and constructs bridges and links from their prior knowledge to that being constructed.

\section{Evaluating Collaborative Efforts}

Three aspects of evaluation are important to collaborative learning. The first is the evaluation of the actual collaborative process to measure the development of interdependency. The second is the evaluation of the group and its success in reaching its goal. The third is the individual evaluation of group members and what they have mastered during the course of the collaboration which equates to the individual accountability considered important to successful collaboration. Research conducted by Slavin (1983) and Johnson and Johnson (1986) indicates that collaboration will be most successful when attention is paid to these three areas. 
Findings in the literature suggest that the evaluation of the collaborative processes occur on an ongoing basis as students de-brief following group sessions (Bosworth, 1994; Gerlach, 1994; Lowry, Osman-Jouchouz, \& Cyr, 1994; Lyman, 1995). Generally, this may involve a few minutes at the end of each group meeting in which students discuss their perceptions about the process and in which they may discuss issues or concerns. In the ideal, students who question equal distribution of effort, attention to or progress toward goals, or any other component of the collaborative process would present this to the group, and if appropriate to the instructor.

Haring-Smith (1993) echoes the importance of evaluating the functioning of the group; she states that because the work of the collaborative process is meaningful, it should be evaluated. As an alternative approach to evaluating the collaborative process, she suggests that an outsider observe the group through one full working session. The observer, she says, would "look especially at how individuals interact. How often does each group member speak? For how long? Who agreed with whom?" (p. 39). Then the observer prepares a report about the group's dynamics.

The weight assigned to each of the three evaluations when formulating a student's grade for the class is under debate. Furtwengler (1995) poses an equal treatment plan, allocating 
evaluation of each of the three areas as a third of the grade. Fiechtner and Davis (1992) in their research on students' responses to collaborative experiences found that students indicated that best experiences were those in which upwards of forty percent of the grade was based upon group performance. Additionally, they found that group exams were positively regarded, up to about four during the course. Interestingly enough, their study also supports the concept of peer evaluations as a means of measuring individual accountability.

A research study by Slavin (1983) found that individual student achievement increased when rewards were made to the group based upon its members' individual learning more than when there were no group rewards. "Group rewards and individual accountability are held to be essential to the instructional effectiveness of cooperative learning methods" (p. 429). Measurement of the individual members' accomplishments within the group should therefore result in a reward for the group, and students should know that it is a basis for rewards. Miller and Harrington (1990) state that team tasks are most effective when they encourage the unique contribution of each individual. "When rewards are dispersed on an individual basis, each team member can experience recognition as a unique contributor and thereby fulfill individual identity needs" (p. 64). Without the balance of the individually based reward, Miller and Harrington found, over- 
emphasis on group rewards tended to result in isolation of members, particularly when groups contained different cultures and ethnicities. The individual recognition was essential for the members' personal validation. Evaluating group processes and products and the individual's accomplishments within the group are equally important in determining grading strategies in the collaborative environment.

Cultural Differences in the Collaborative Environment

There is nothing implicit within the concept of collaborative learning which insures that all voices and cultures can be heard. Quite the contrary. The style itself may conflict with some cultural ways of knowing. Heterogeneity in collaborative groups appears to work best; however, that may well depend upon the ability of the instructor to consider that not all students think and learn alike. Shared vision and common goals are believed to be a critical component in creating collaborative environments. Although these can help enhance a collaborative process, the reality is that groups are likely to be extremely diverse -- both in terms of interests and origins.

\section{Cultural Difference}

Diversity and difference usually bring to mind evident, usually physical characteristics such as race, sex, language or physical 
capability. While these may play a role in group dynamics and success within a collaborative environment, the impact may be greater, though unexpected, from subtler, less evident differences. According to Condon (1986), culture is "how the student has been taught to view the world and to act and react" (p. 14).

Brilhart and Galanes (195) expand on this concept by describing five broad characteristics that differ from culture to culture. These are world view, or one's relationship to it and the purpose of life; individualism versus collectivism, whether the group or the individual is the driving force; power distance, in which low distance would equate to democracy and high to authoritarianism; uncertainty avoidance, whether ambiguity and risks are acceptable or rigid rules are necessary to provide security; high versus low context continuum in which low relates to meaning explicitly expressed or high in which meaning is conveyed by features of the situation.

These are the subtle differences which result in big confusion because of the tendency to assume everyone is "like me." Condon (1986) reminds us that the academic culture is a mirror of the American and becomes reflected in the communication within the classroom, establishing norms such as who is encouraged, how interruptions are dealt with, to what extent students (and instructors) may self-disclose, and patterns of conflict. 
In the fervor of the 'valuing diversity' bandwagon, bell hooks (1994) said "many folks found that as they tried to respect 'cultural diversity' they had to confront the limitations of their training and knowledge, as well as a possible loss of 'authority'" (p. 30). The expressions of respecting differences and involving everyone equally inspired enthusiasm and hopefulness. But, as hooks experienced, "The fact of the matter is that the progressive vision of cultural diversity may mean antagonism in the classroom--not the soupy, nice, harmony some talk about" (p. 30).

The issue then, is not to imbibe instructors with the ability to level the field, create equality and dilute the differences. But, rather to instill in instructors the art of allowing the differences to enrich the collaborative environment much as the large boulders in the stream create the beauty of the rapids.

\section{Value of Diversity in Collaborative}

\section{Environments}

Through collaborative learning, however, bridges between differences can be built. Creating a collaborative environment is based upon a respect for the contributions of others and upon developing the interdependence among students. Collaboration, in the ideal, is an environment in which to present and work with different ways of knowing. Smith and MacGregor (1992) have said that through 
collaboration are built "capacities for tolerating or resolving differences, for building agreement that honors all the voices in a group, for caring how others are doing" (p. 11).

Several studies at the elementary school level indicate that collaborative groups can reduce tensions between members of different groups and increase positive interaction between them. HertzLazarowitz and Shachar (1990) posed that collaborative group "investigation reduces the salience of personal background variables" (p. 85). Kagan, in an interview with Brandt (1990) reported that race relations improved among students in cooperative groups. Miller and Harrington (1990) found that a competitive environment served to differentiate students from members of other groups as they strove to maintain their identity. Cohen (1986) found that collaborative work provides an opportunity for students to question and dissolve cultural prejudices.

Building relationship and constructively incorporating differences within the college level collaborative environment, however, continue to challenge instructors. As Billson (1994) said, "Diversity of backgrounds and interests can add to the richness of classroom interaction; they can also contribute to misunderstandings, conflict and uneven participation" (p. 22). 
Even while differences may seem disruptive, Bruffee (1995) considers that "resisting the task, rebelling against the teacher, and questioning each other's views within a group may be inevitable and often necessary aspects of learning" (p. 17). The popular democratic model of collaborative learning described by Hamilton (1994) elaborates this concept from the work of Trimbur (1993). In this model, instructors are challenged not to eliminate differences but to capitalize on them. Hamilton (1994) suggests "envision[ing] these essential differences as catalysts for the making of meaning within the specific concepts of the particular course" (p. 95). Through collaborative learning, instead of students adopting the culture of the discipline, they contribute their uniqueness through "multi perspective negotiations about the governing paradigms and tacit traditions of the subject and course and whether they should still govern, remain tacit, and remain traditions" (p. 96). This approach acknowledges that the traditions and culture of the course are generated from the dominant culture without granting special authority to it.

The principle challenge for instructors is to avoid gracing the authority of their knowledge and ways of knowing with any power. Condon (1986) states that instructors need to be "more aware of one's own cultural assumptions and behavior"(p. 19) and "to resist making 
negative judgments of students from very different backgrounds when their behavior does not conform to one's expectations" (p. 19).

\section{Cultural Clash}

Though there may be literature about dealing with differences in the college classroom (sparse though it is), there is really very little guidance to instructors about how to create classrooms which accept, incorporate and value the diversity of cultures within them.

Instructors know that they must be "tuned in to" the presence of diversity, that there are different ways of knowing, different norms and values of time, space, and non-verbal signals. But, they do not know how to effectively address that in the classroom. This is another significant challenge for instructors creating meaningful collaborative environments.

Just as instructors teach as they were taught, so do they teach from the cultural frame in which they exist. Without even being aware of it, instructors carry cultural assumptions into the classroom. To present a rudimentary example, Haring-Smith (1993), in her handy guide to collaborative learning, instructs students to "look directly at the people you are talking to and ask them if they understand what you are saying. Watch people's faces for signals that you are communicating clearly or not" (p. 20). These instructions are valuable 
if all students represent the dominant culture; they may not be effective, and in some cases can be contrary, when cultural norms of the students do not value meeting people's eyes, or when non-verbal signals differ.

Another example of the unanticipated cultural clash is the elementary school teacher who incorporates relaxation exercises into her daily curriculum as a means of slowing students down, and in the vernacular of the day, mellowing them out. Many who have, with all the best intentions, included relaxation have faced the backlash of the fundamentalists who view it as contrary to their religion even though the relaxation exercise is not a religious practice.

These two examples are the visible edge of cultural clash. Even deeper lies the hidden assumptions which influence choice of text, language, presentation, content focus. Bowers (1996), in a discussion with the author, said that it was important to look at what was unsaid and what messages that silence may carry. Within what is unstated are the assumptions and cultural biases which impact how collaboration really works. 


\section{Awareness}

Brilhart and Galanes (1995) identify several guidelines which contribute to effective incorporation of difference. The first is to enter every discussion knowing that it is intercultural and not to assume that if the students look alike, they think alike or learn alike. The second is to move away from one's own ethnocentricity and recognize the differences without valuing them one way or the other. Thirdly, examine whether an action of a student is a result of culture rather than stupidity or ill intent. Fourth, and perhaps the most delicate and difficult to learn to do gracefully, initiate discussions about difference; it is folly to attempt to make them invisible. And fifth, adapt to the differences, modifying the course, texts, group assignments or other aspects of the class to insure the opportunity to value those differences.

Valuing and effectively encouraging differences in the traditional classroom presents challenges to instructors, but, when creating collaborative environments the challenge is multiplied by the number of students in the class. Not only does the instructor have to be aware of the cultural orientation of the content, texts, and presentation, the instructor must also be cognizant of the blend of cultures between students as they seek to work collaboratively and generate knowledge. Trimbur (cited in Wiener, 1986) stated that effective collaboration will 
cause students "to recognize and tolerate differences and at best to see the value systems, set of beliefs, etc. that underlie these differences" (p. 54). The ideal collaboration elicits difference, works with it, adds to each participant's repertoire and strengthens the quality of the group work and product.

Cultural awareness that focuses finitely on the stereotypical ways of being and responding and which are aligned within the limits of race, gender, ethnicity, or language, limit and deplete the ability of an instructor to create the appreciation for differences which strengthens the collaborative environment. Schriner (1992) states that "data demonstrate that difficulty with the discourse conventions of the academy is a primary factor in the [attrition figures of ninety percent among Native Americans at Northern Arizona University]" (p. 96). The charge for the college instructor is to create the opportunity for all students to express their own voice, to connect with their own identity without conventional restrictions which limit them.

This charge is no easy feat. As bell hooks (1994) said "Most students are not comfortable exercising this right [of free speech]-especially if it means they must give voice to thoughts, ideas, feelings that go against the grain, that are unpopular" (p. 179). Ways to open the classroom to the necessity of genuine expression of voice are essential to the instructor. Just as students need to understand the 
concept of collaboration before they are launched into collaborative activities, they need to be introduced to ways in which they may speak in their own voices and express and identify those elements in the course content, text and collaboration which seem to exclude other voices.

Schriner (1992) poses viable suggestions for introducing students to the freedom of voicing their own identities through emphasizing everyone's particularity. She said:

We begin by deciding that our curriculum must first recognize all students as being multi-cultural and all as having experience moving between and within communities of open rather than closed borders. We then decided that the curriculum must provide opportunities for examining the movement across these borders, as well as opportunities to explore and understand how they are both creator of and created by their multi-cultural social realities. (p. 98)

The collaborative environment lends itself well to inviting different voices. I believe that community works best through a mingling of differences and acknowledgement of their existence. For instructors to be fully successful in creating collaborative environments, they must be open to exploring their own assumptions about the materials, content and language of the course curriculum. Additionally, they must introduce students to the freedom to see with their own view and speak with their own voice. Successful 
collaboration depends upon the both the instructor's self examination and encouragement provided to students to express themselves.

\section{Summary}

The research indicates that retention of learning and development of critical thinking are enhanced in collaborative environments. In collaboration, students are dependent upon each other for the creation of knowledge while at the same time they individually master the new information. Collaborative learning has the potential to excite students as they learn. The skills of collaboration which students learn are invaluable in the workplace where team projects are becoming standard.

For all its stated advantages, collaborative learning does not come easily to either students or instructors. Old habits die hard, as teachers tend to teach as they were taught and students expect to be filled with knowledge and told what the answers are. The stumbling blocks for instructors in creating collaborative learning environments are the challenges of moving from traditional ways of teaching to the collaborative.

The optimum environment for effective collaboration, based upon the literature, is one in which trust is present, relationships are important, everyone contributes and reflects upon the process itself 
and in which the teacher is also a learner. Everything within the collaborative experience contributes to its creation. Assignments further a trusting environment, contribute to and depend upon interaction from all. Teachers model and teach collaborative skills. Students accept responsibility for their own learning.

To create the kind of collaborative experience described within the literature, instructors must learn how to teach social and collaborative skills, be careful listeners and encouragers of conversation and guide students through constructive reflection. This must be done within the context of the content and be balanced by technical skills such as knowing ways to assign students to groups, design and assign tasks and activities, and evaluate the quality of the group process and product and the contribution of the individual student.

The concepts from the literature which will inform the development of the curriculum are displayed in Table 1, which follows. 
Table 1

Implications from the Literature for Inclusion
in the Curriculum

\begin{tabular}{|c|c|c|}
\hline $\begin{array}{l}\text { Collaborative learning } \\
\text { requires: }\end{array}$ & $\begin{array}{l}\text { which means that } \\
\text { instructors must: }\end{array}$ & $\begin{array}{l}\text { and that collaborative } \\
\text { activities: }\end{array}$ \\
\hline trust & $\begin{array}{l}\text { self-disclose and create } \\
\text { safe environments }\end{array}$ & invite all contributions \\
\hline $\begin{array}{l}\text { development of } \\
\text { relationships }\end{array}$ & $\begin{array}{l}\text { teach social and } \\
\text { collaborative skills }\end{array}$ & create a need to talk \\
\hline conversation & $\begin{array}{l}\text { encourage and model } \\
\text { through conversation } \\
\text { and communication }\end{array}$ & $\begin{array}{l}\text { involve talk and } \\
\text { working with the } \\
\text { problem presented }\end{array}$ \\
\hline $\begin{array}{l}\text { incorporating } \\
\text { differences }\end{array}$ & $\begin{array}{l}\text { explore own } \\
\text { assumptions }\end{array}$ & $\begin{array}{l}\text { not be based upon } \\
\text { unknown assumptions } \\
\text { and include no easy } \\
\text { answers }\end{array}$ \\
\hline evaluation of process & $\begin{array}{l}\text { know how to make use } \\
\text { of reflection }\end{array}$ & $\begin{array}{l}\text { allow opportunities for } \\
\text { reflection }\end{array}$ \\
\hline $\begin{array}{l}\text { time to discuss, } \\
\text { process, reflect }\end{array}$ & $\begin{array}{l}\text { allow in class group } \\
\text { work }\end{array}$ & $\begin{array}{l}\text { be time bound and } \\
\text { achievable }\end{array}$ \\
\hline everyone be learners & $\begin{array}{l}\text { be willing to relinquish } \\
\text { authority }\end{array}$ & have no "right" answers \\
\hline constructive conflict & $\begin{array}{l}\text { assess when it's gone } \\
\text { too far }\end{array}$ & \\
\hline
\end{tabular}


CHAPTER III

\section{PROCEDURES}

\section{Curriculum Development Methods}

Through the review of literature, it is apparent that little in the way of comprehensive guidelines or instruction exist for those interested in developing skills to create collaborative learning environments in the college classroom. Instructors may know that collaboration is important in the work place, that it is reputed to enhance achievement and knowledge retention and that faculty leaders encourage it in higher education. But, they may not have the awareness of the stumbling blocks to effective collaboration. The purpose of this study is to design a curriculum to guide instructors around those stumbling blocks to the experience of genuine creation of knowledge through collaboration.

With a firm belief in the value of collaboration, gained both through educational and work experiences, it would follow that I use a collaborative approach to the curriculum design process. As much as possible, the evolution of the curriculum ideas generates from a conscientious group of faculty who are committed to collaboration in 
the classroom. One on one interviews with these faculty provide the foundation for articulating a curriculum for college level and adult education or training instructors in any discipline.

\section{Contributing Faculty}

The faculty interviewed are known to apply collaborative learning within their classrooms. Questions asked focus on their experiences creating collaborative environments. Their ideas and lessons from these experiences inform the development of the curriculum both within this study and continuing until the curriculum is ready for presentation.

\section{The Interview}

The interview was used to validate findings discussed in the previous chapter and to learn about the success experiences of the faculty. Interview questions focus on the faculty member's experience with collaboration, skills that are important, ways in which skills were developed and difficulties encountered in the collaborative classroom and successes in their resolutions.

Specifically, the questions asked of each faculty interviewed include: What are your experiences with collaborative learning? What are the characteristics of an effective collaborative learning environment? What challenges have you faced in creating 
collaborative learning experiences and how have you dealt with them? What are the skills you believe are essential for instructors creating collaborative environments? In what way have cultural differences within groups impacted the creation of the collaborative environment? And, how have you factored these differences into your collaborative efforts? What impact does creating collaborative experiences have on course content? What advice would you give to other faculty interested in using collaborative learning in the classroom? The interview guide is found in Appendix A.

\section{Procedures}

The results of the interviews were examined to learn about current practices in collaborative learning as guidance for the development of the curriculum ideas. The curriculum was developed using a process posed by Caffarella (1994). Caffarella suggests an 11 component interactive model for program planning which provided the frame for the curriculum envisioned. Table 2 presents the 11 component interactive model and highlights those components which apply in the creation of this curriculum. The remaining components apply at the point of implementation of the curriculum. 
Table 2

Caffarella's Interactive Program Development Model

\begin{tabular}{|c|c|c|}
\hline $\begin{array}{c}\text { Interactive Program } \\
\text { Planning Model }\end{array}$ & $\begin{array}{l}\text { Consider in this } \\
\text { Study }\end{array}$ & $\begin{array}{l}\text { Potential Follow-Up } \\
\text { Study } \\
\end{array}$ \\
\hline $\begin{array}{l}\text { Establishing a basis for } \\
\text { the planning process }\end{array}$ & $\begin{array}{l}\text { Gain faculty support for } \\
\text { the concept }\end{array}$ & Practical effort in follow-up \\
\hline Identify program ideas & $\begin{array}{l}\text { Through literature review } \\
\text { and faculty interviews }\end{array}$ & \\
\hline $\begin{array}{l}\text { Sorting and prioritizing } \\
\text { ideas }\end{array}$ & $\begin{array}{l}\text { Initial sorting and } \\
\text { prioritizing }\end{array}$ & $\begin{array}{l}\text { Secure faculty support for } \\
\text { prioritization }\end{array}$ \\
\hline $\begin{array}{l}\text { Developing program } \\
\text { objectives }\end{array}$ & Develop independently & $\begin{array}{l}\text { Confirm faculty agreement } \\
\text { with objectives }\end{array}$ \\
\hline $\begin{array}{l}\text { Prepare for the transfer } \\
\text { of learning }\end{array}$ & $\begin{array}{l}\text { Embedded within } \\
\text { curriculum }\end{array}$ & $\begin{array}{l}\text { Collaborate with faculty in } \\
\text { development }\end{array}$ \\
\hline Form evaluation plans & $\begin{array}{l}\text { Propose in instructional } \\
\text { plans }\end{array}$ & $\begin{array}{l}\text { Consult with Faculty and } \\
\text { assessment specialists }\end{array}$ \\
\hline $\begin{array}{l}\text { Formats, schedules and } \\
\text { staff needs }\end{array}$ & $\begin{array}{l}\text { Include format in } \\
\text { instructional plans }\end{array}$ & \\
\hline \multicolumn{3}{|l|}{ Budgets and marketing } \\
\hline $\begin{array}{l}\text { Design instructional } \\
\text { plans }\end{array}$ & Preliminary plans & $\begin{array}{l}\text { Modify through } \\
\text { collaboration with faculty }\end{array}$ \\
\hline \multicolumn{3}{|l|}{ Coordinating facilities } \\
\hline $\begin{array}{l}\text { Communicating the } \\
\text { value of the program }\end{array}$ & & $\begin{array}{l}\text { Build upon with faculty } \\
\text { and administrators }\end{array}$ \\
\hline
\end{tabular}

(Shading shows components addressed in this study)

Though these are expected to be interactive and not bound to a particular order, the discussion begins from the component at the top and proceed downward. The first component is establishing a basis for the planning process in which two keys are gaining the support of the faculty team involved in the planning and understanding the 
context in which planning occurs. The second component, identifying curriculum ideas, occurred in part through the review of literature presented in Chapter II; additional curriculum ideas result through the evaluation of the interviews. Caffarella (1994) emphasizes that the model is not linear, but is intended to be interactive, encouraging flexibility and a flow in, through and around the components as the circumstances indicate may be needed.

The third component, sorting and prioritizing of program ideas, is critical to the curriculum conception. As has been seen in the literature review, the diversity of approaches to discussing collaborative learning is significant. Review of the faculty interviews contributed to the determination of ideas with the most impact in the curriculum.

Once the curriculum ideas have been sorted through and prioritized, the next component involves development of the program objectives which follow from the ideas selected for the program. Of consideration in specifying program objectives is the target audience and the issues of format. Instructors and/or trainers committed to creating more successful collaborative environments, either within the class room or the work place, are the target audience. In the ideal, the objectives lead to the creation of a curriculum which would be flexible enough to adapt to either a full semester as a regular college course 
college course within a school of education, a graduate level course within a discipline area or to a seminar or weekend workshop within the education and/or business world.

The fifth component is unquestionably one of the most important, preparing for the transfer of learning, or insuring that the participants are able to apply and use the knowledge and information learned once they complete the course. Within the proposed curriculum, transfer of learning activities are found at the beginning, during, and at the conclusion of the course to verify that progress toward learning occurs and that participants are able to make use of the knowledge.

Mechanisms for evaluating the curriculum's effectiveness and the ability to reach stated objectives were built in as a part of its design. Caffarella (1994) states "good program evaluation provides useful feedback to program planners, participants, supervisors or participants, managers and administrators, community groups, and other interested parties" (p. 120). Strategies to insure the value of the program will be a strong selling point to the colleges, training centers and businesses to whom it will be marketed.

The format for the curriculum is suggested as a part of the proposal as it pertains to the length of course; this is for illustrative purposes only. Other variations could easily be adapted from that 
presented within the proposal. Details of format, scheduling, and determination of staff needs are not intended to be elements of this study. Likewise, the component addressing budgeting and marketing is not considered in this study.

The component for the design of instructional plans for the curriculum is significant. The instructional plans were drafted by the author based upon the contributions of the faculty interviewed and the literature reviewed. The instructional plans provide the learning objectives, identifying what the students in the course will know and be able to do following the course. The instructional plans also lay out the order in which content areas are presented and the techniques to be used. Obviously, with the focus of the course being collaborative learning, the instructional plans are designed such that students collaboratively learn and practice the skills essential to effective collaboration as an integral part.

The curriculum designed as a part of this study is offered as a proposal. Actual implementation is an ultimate goal. Only at the stage of planning for the implementation does the component for coordinating facilities become pertinent.

Communicating the value of the program is the remaining component of Caffarella's (1994) interactive model which serves as the skeleton upon which the course has been built. This component is of 
significant importance in that it may very well become the means for marketing the curriculum once it is finalized. Results of the literature review lend credence to the program's value.

The following chapter reports on the components of the curriculum design process as conceived based upon interview and literature review results. Chapter V details elements of the proposed course which is presented in Appendix C. 


\section{CHAPTER IV}

\section{RESULTS}

\section{Creating the Curriculum}

This chapter presents the program development processes posed by Caffarella (1994) as applied to the creation of the curriculum to guide instructors in using collaborative learning as a teaching method. Each step of the development process is discussed and includes a blending of the literature review findings with those of the faculty interviews. As described in the previous chapter, faculty members were interviewed with two purposes in mind. One, to validate the findings in the literature review, and two, to learn directly about their experiences in creating collaborative environments. The experiences of the faculty interviewed inform the development of the curriculum for instructors. From this process evolves the course proposal which is discussed in Chapter V.

Establishing a Basis for the Planning Process

Caffarella (1994) emphasizes the importance of building a base of support for the program development. For the curriculum being 
designed, the support of committed faculty was considered to be critical. It is one thing to believe in isolation that a course for instructors to learn how to create collaborative environments would be of value and it is another to have that belief confirmed by others.

The context in which the planning occurred became a factor, as Caffarella (1994) indicates. The program development process involved internal factors, such as scheduling faculty interviews. External factors would likely not be dealt with until a specific application for the curriculum occurred. Then, consideration for external factors like the agency offering the curriculum and its perception of the potential participants, would become important.

\section{Gaining Faculty Support}

Nine faculty members were invited to participate in the one on one interviews; seven, accepted the invitation. Through the discussion of the interview results, faculty will be referred to by an alphabetic letter designation rather than by name. The interview guide used for each interview is included in Appendix A. Faculty members interviewed include one community college instructor, three School of Education graduate program faculty, and three undergraduate level faculty, two of which are also involved in faculty development. This breadth of experience inspired questions which are not addressed by 
this study but are worth some thought. Namely, what are the differences between creating collaborative environments for lower division students and for upper division or graduate level students? What is the role of conflict in the collaborative group? Are there some who cannot collaborate?

All those interviewed expressed enthusiasm for the goals of the study and interest in its outcome. It was apparent that there was strong commitment to the concepts of collaborative learning and to helping others use it as a teaching method. Several interviews were conducted during the faculty member's personal time and at some inconvenience which was a measure of their interest. Many of those interviewed indicated that the questions caused them to reflect in new ways on their experiences with and approach to collaborative learning. Most asked to review the resulting document.

\section{Context of the Planning}

In the ideal, the belief in collaboration would lead one to collaboratively create a curriculum. A truly collaborative process would have involved several meetings of the faculty interviewed as an arena for them to contribute their voice and ideas to the curriculum creation. Unfortunately, one of the constraints of the context for 
planning was the demanding schedules of the faculty and the author. Group collaboration was not possible.

The compromise became gathering ideas from the faculty through the interview process. Then, I categorized and evaluated their suggestions and contributions as a part of the curriculum development process.

Identifying and Selecting Program Ideas

The collaborative learning curriculum generates from the ideas revealed in the literature coupled with those contributed by the faculty through the interviews. As stated in Caffarella (1994), programs are designed to serve a need which implies a difference between what is and what is desired. In the case of collaborative learning, the literature review indicates that there are benefits to students who learn in collaborative groups and that there are faculty who do not know how to create collaborative environments, perhaps because training in what makes collaborative learning work has not been available. The need then, is to design a course to help faculty know how to create environments in which collaborative learning can occur. In the previous chapter, curriculum ideas were gathered from the review of literature. Briefly, the literature indicates that collaborative learning requires trust, incorporating differences, the 
instructor relinquishing authority and students accepting personal responsibility for their learning. Instructors, then, must be able to teach social and collaborative skills, apply and understand the use of reflection in collaboration, encourage careful listening and conversation. This is in addition to the technical skills required of assigning groups, designing and assigning tasks and evaluating quality of product, process and person.

In the next section, ideas from the faculty are presented and compared to those from the literature. Then, ideas are blended, refined and developed into the curriculum objectives.

\section{Curriculum Ideas from Faculty Interviews}

Faculty interviews resulted in confirming much of what was learned through the literature review. The faculty described experiences which accentuated the principles of building trust, focusing on relationships, incorporating differences, and from the instructor's view point, gaining comfort with relinquishing authority for learning. In this section, ideas from the interviews which matched those from the literature are discussed, followed by ideas expressed by faculty but which were not emphasized in the literature.

Ideas matching the literature. More than half of the faculty interviewed mentioned the importance of learning collaborative skills 
to be successful in the work place. It is expected in the work place. When students complain about having to work in groups, instructors draw the relationship between the requirement for collaboration in the class and that expected in the world of work. My experiences within the work place likewise indicate that this is a necessary skill. Three of the faculty interviewed stated that it was important to explain the reasons for using collaborative learning.

Preparing the students to work collaboratively was mentioned as a critical component by all the faculty interviewed just as it was in the literature. Faculty "E" described the first course in which she used collaboration but had not included preparatory work in collaboration for the students. Much of the time expected to be spent collaborating was spent floundering. In future courses, a component to acquaint the students with collaboration and group process skills was included.

Although it may enhance any classroom, within the collaborative environment, getting to know the students can make or break the success of the experience. According to the faculty and the literature, through knowledge of the students, the instructor gains the trust and builds the safe environment critical to collaboration. Learning about students, said the faculty, also contributed to effective modification of the activities or to problem solving in the course of the collaboration. 
Once the assignment is described and group members are actively working on collaboration, the five of the interviewed faculty described their role as one of facilitator, with the responsibility for modeling the collaborative skills expected of students and carefully observing the process. Listening, clarifying and effectively communicating are skills described by the literature and the faculty as part of the instructor's modeling role. As facilitator, the faculty described their tasks as keeping the process on track, making it fun and constructively guiding conflict.

All faculty emphasized not just the time which must be allowed for students to collaborate, but the importance of having them reflect upon the process, using discussions, journals or reflection papers of some sort. Building this into the structure of the collaborative assignment is recommended both through the literature review and the faculty interviews.

Assignments which work best, as the faculty described them, are those which are specific, time bound and achievable. The Faculty recommended keeping in the forefront the goal of the assignment and the intent of the collaborative process.

Evaluation ideas expressed by the faculty included providing regular feedback to the groups and the individuals and as mentioned previously, the use of journals and reflections. During the course of 
the collaboration, students benefit from feedback about the group process and their individual achievement. One faculty member advocated the use of peer evaluations. All mentioned balancing the evaluation of the success of the group with the individual's success. Evaluation strategies mentioned by faculty considered the three components identified in the literature: evaluation of the process, product and person.

The question about dealing with cultural differences in collaborative groups inspired many suggestions from the faculty. Five of the faculty recommended approaching collaboration from an inclusion philosophy in which every member has a voice. It is just as evident from the interviews as it was in the literature that, as one faculty member stated, "We're very inadequate," ("C") dealing with cultural differences in the classroom and that it is a continuing challenge. Encouragingly, many of the suggested strategies would enrich any collaborative group because of the focus on creating an emotionally safe environment, encouraging voice and open discussion of differences.

New ideas from the faculty. Interestingly, two faculty specifically mentioned the place of democracy within the collaborative environment. Three others alluded to the democratic aspects of collaboration through mentioning the importance of insuring that 
every voice be heard, that every group member participate. A quote which exemplifies the democratic philosophy is, "When it works, the day is won by the point, not the power" ("C"). Another is "Group work is about every one taking turns" ("B"). This concept goes a long way toward forwarding the inclusion philosophy emphasized to invite expression of differences.

One method of insuring that all students contribute, as suggested by the faculty, is the development of ground rules for collaboration. Creation of these rules may be done as a part of the initial process of preparing students for collaboration. Ground rules can provide: a safety valve for students who feel vulnerable in the collaborative arena; a trigger for curtailing nonproductive conflict; a mechanism to insure everyone has a turn.

Faculty discussed the requirement for instructors in collaborative environments to be able to accept ambiguity and the unexpected and the need to be flexible. As "A" expressed it, "you can't control the chemistry." There is no cookie cutter pattern for collaborative learning because, as the faculty stated, each group is different.

The intensity of the instructor's pre-planning for the collaborative learning experience was more strongly emphasized by faculty than was apparent in the literature. During the collaborative 
event, the requirement for the instructor to be flexible is key. But, it is careful ahead planning that frees instructors to be flexible, deal with ambiguity and respond to the unexpected with more ease.

Interestingly, many indicated that they discussed the various roles within a group, and even suggested initially assigning roles to members. This contradicted much of the literature which specified providing a specific project to the collaborative groups and providing them no external structure. However, the faculty interviewed believed that the discussion and early use of roles helped sustain groups through difficult transitions.

Faculty discussed the impact on content of collaborative learning. Most felt that it has the potential to bring deeper understanding, provide more depth and enriches that which students learn. Faculty "B" said that through collaboration the "content is uncovered, rather that covered." She sees collaboration as a process of discovery. Even though content can be richer and explored by students in more depth, as three faculty indicated, not every class is appropriate for collaborative learning. Context, time, resources and logistics such as space must be examined.

Table 3 displays the curriculum ideas presented and indicates the faculty members from whom they came. 
Table 3

Faculty Suggestions for Curriculum Ideas

\begin{tabular}{|l|c|c|c|c|c|c|c|}
\hline \multicolumn{1}{|r|}{ Faculty : } & $\mathrm{A}$ & $\mathrm{B}$ & $\mathrm{C}$ & $\mathrm{D}$ & $\mathrm{E}$ & $\mathrm{F}$ & $\mathrm{G}$ \\
\hline $\begin{array}{l}\text { Ideas: } \\
\text { Work place }\end{array}$ & $\mathrm{X}$ & & $\mathrm{X}$ & $\mathrm{X}$ & $\mathrm{X}$ & $\mathrm{X}$ & \\
\hline Reasons & $\mathrm{X}$ & & & $\mathrm{X}$ & & & \\
\hline Democratic & $\mathrm{X}$ & $\mathrm{X}$ & $\mathrm{X}$ & $\mathrm{X}$ & & & $\mathrm{X}$ \\
\hline Flexibility & $\mathrm{X}$ & $\mathrm{X}$ & $\mathrm{X}$ & & $\mathrm{X}$ & $\mathrm{X}$ & $\mathrm{X}$ \\
\hline Planning & $\mathrm{X}$ & $\mathrm{X}$ & & & $\mathrm{X}$ & & $\mathrm{X}$ \\
\hline Prepare students & $\mathrm{X}$ & $\mathrm{X}$ & $\mathrm{X}$ & $\mathrm{X}$ & $\mathrm{X}$ & $\mathrm{X}$ & $\mathrm{X}$ \\
\hline Roles & & & $\mathrm{X}$ & $\mathrm{X}$ & $\mathrm{X}$ & & $\mathrm{X}$ \\
\hline $\begin{array}{l}\text { Is class } \\
\text { appropriate }\end{array}$ & $\mathrm{X}$ & $\mathrm{X}$ & & & & & $\mathrm{X}$ \\
\hline Reflection & $\mathrm{X}$ & $\mathrm{X}$ & $\mathrm{X}$ & $\mathrm{X}$ & $\mathrm{X}$ & $\mathrm{X}$ & $\mathrm{X}$ \\
\hline Modeling & $\mathrm{X}$ & $\mathrm{X}$ & $\mathrm{X}$ & & & $\mathrm{X}$ & $\mathrm{X}$ \\
\hline Fun & & $\mathrm{X}$ & & $\mathrm{X}$ & & $\mathrm{X}$ & \\
\hline $\begin{array}{l}\text { Evaluation of } \\
\text { group and } \\
\text { individuals }\end{array}$ & $\mathrm{X}$ & $\mathrm{X}$ & $\mathrm{X}$ & $\mathrm{X}$ & $\mathrm{X}$ & $\mathrm{X}$ & $\mathrm{X}$ \\
\hline All voices & & & & & & & \\
\hline
\end{tabular}

Key Thoughts from Faculty. Concepts mentioned by the interviewed faculty have become integrated into the curriculum. The most frequently mentioned were the importance of preparing students to work collaboratively, incorporating some means for students to reflect on the process, and balancing the evaluation of the group and 
the individual members. These concepts are major components of the curriculum.

Most faculty also mentioned the importance of modeling the collaborative skills expected of students. This is articulated in the curriculum in the session covering the instructor as facilitator. But more critical to the course's eventual success is the ability of the instructor to practice modeling during the course.

As most of the faculty pointed out, even though the instructional plans may set the road map for delivery of the course, flexibility and being able to adapt quickly to changing circumstances are essential in any collaborative environment. If the proposed course is presented, the instructor will need to be open to making instantaneous changes. Three faculty emphasized that each class is different and what works in one may not in another. Collaborative learning environments are unpredictable.

\section{Selecting Curriculum Ideas}

Myriad ideas for the curriculum are evident, both through the literature and the faculty interviews. As indicated in the previous section, faculty interviews significantly mirrored the literature. In this section, the major principles revealed are presented and the 
implications for the curriculum explored as ideas are selected for inclusion.

Instructors creating collaborative environments must know more than the course content material to effectively teach students. From the literature it was discovered that instructors must learn how to:

- $\quad$ create safe environments

- teach social and collaborative skills

- encourage and model conversation and collaborative skills

- $\quad$ explore their own assumptions

- make use of reflection to evaluate process

- $\quad$ provide meaningful feedback

- $\quad$ create activities which depend upon interaction from all students

- relinquish the role of authority and assume the role of facilitator.

Through the faculty interviews, several other requirements for instructors were uncovered. Instructors must learn to:

- $\quad$ accept ambiguity and practice flexibility

- $\quad$ concentrate on pre-planning

- evaluate content to determine impact of collaboration

- determine where students are on the collaboration continuum (discussed below). 
Careful consideration of the faculty ideas begins to reveal an "evolving" collaboration, almost a collaboration continuum. In a class of students less comfortable or experienced with collaborative learning, the instructor will need to focus more attention on teaching students social and collaborative skills and insuring a trusting and safe environment. This is the structured end of the continuum. If students have more experience with collaborating in the classroom, less attention will be needed to prepare them for the experience. This is the no structure end of the continuum.

From the literature, I find that Bruffee (1993) aligns with the less structured end of the continuum. He describes collaborative learning as functioning best with little interference from the instructor. He recommends against role assignments within groups and teacher led process evaluation. He believes that students should be provided a skeletally structured assignment with limited details, which are then the responsibility of the collaborative group.

At the structured end of the continuum is Cooper and Meuck (1992), who define their concept as necessitating considerable instructor-imposed structure.

The experience of the faculty amplifies the continuum. The extent of structure, role assignment or ground rule development must be based upon the ability of students to function within the 
collaborative environment. Obviously, this is why it is essential to learn about the students and determine the need to teach some type of group process skills. The extent of instructor involvement or instructor-imposed structure, the author concludes from the literature and the interview results, seems to be a factor of the students' abilities to grasp the collaborative concept and do it.

The curriculum is designed around the principles discussed with the intent of preparing instructors, through experiential opportunities, to understand the work of creating a collaborative environment. Table 1 within Chapter II demonstrated the relationship between the requirements for collaborative learning and the instructor's responsibility as understood from the literature. This is expanded upon in Table 4 below, to incorporate the findings from the faculty interviews which are distinct from the literature. 
Table 4

\section{Characteristics of Collaborative Learning Environments: Implications from Faculty Interviews and the Literature for Inclusion in the Curriculum}

\begin{tabular}{|c|c|c|}
\hline $\begin{array}{l}\text { Collaborative learning } \\
\text { requires: }\end{array}$ & $\begin{array}{l}\text { which means that } \\
\text { instructors must: }\end{array}$ & $\begin{array}{l}\text { and that collaborative } \\
\text { activities: }\end{array}$ \\
\hline \multicolumn{3}{|c|}{ Principles from the literature and confirmed through the faculty interviews: } \\
\hline trust & $\begin{array}{l}\text { self-disclose and create } \\
\text { safe environments }\end{array}$ & invite all contributions \\
\hline $\begin{array}{l}\text { development of } \\
\text { relationships }\end{array}$ & $\begin{array}{l}\text { teach social and } \\
\text { collaborative skills }\end{array}$ & create a need to talk \\
\hline conversation & $\begin{array}{l}\text { encourage and model } \\
\text { through conversation } \\
\text { and communication }\end{array}$ & $\begin{array}{l}\text { involve talk and working } \\
\text { with the problem } \\
\text { presented }\end{array}$ \\
\hline incorporating differences & $\begin{array}{l}\text { explore own } \\
\text { assumptions }\end{array}$ & $\begin{array}{l}\text { not be based upon } \\
\text { unknown assumptions } \\
\text { and include no easy } \\
\text { answers }\end{array}$ \\
\hline evaluation of process & $\begin{array}{l}\text { know how to make use } \\
\text { of reflection }\end{array}$ & $\begin{array}{l}\text { allow opportunities for } \\
\text { reflection }\end{array}$ \\
\hline $\begin{array}{l}\text { time to discuss, process, } \\
\text { reflect }\end{array}$ & $\begin{array}{l}\text { allow in class group } \\
\text { work }\end{array}$ & $\begin{array}{l}\text { be time bound and } \\
\text { achievable }\end{array}$ \\
\hline everyone be learners & $\begin{array}{l}\text { be willing to relinquish } \\
\text { authority }\end{array}$ & have no "right" answers \\
\hline constructive conflict & $\begin{array}{l}\text { assess when it's gone } \\
\text { too far }\end{array}$ & \\
\hline \multicolumn{3}{|c|}{ Principles provided by the faculty: } \\
\hline democracy & teach taking turns & $\begin{array}{l}\text { broad enough for the } \\
\text { collaborative group to } \\
\text { add their uniqueness }\end{array}$ \\
\hline comfort with ambiguity & $\begin{array}{l}\text { be flexible and able to } \\
\text { deal with the } \\
\text { unexpected }\end{array}$ & $\begin{array}{l}\text { be easily modified as the } \\
\text { situation indicates }\end{array}$ \\
\hline pre-planning & $\begin{array}{l}\text { invest the time for } \\
\text { intense pre-planning; } \\
\text { consider content }\end{array}$ & $\begin{array}{l}\text { be skeletally } \\
\text { constructed prior to } \\
\text { class }\end{array}$ \\
\hline $\begin{array}{l}\text { knowledge of the } \\
\text { students }\end{array}$ & $\begin{array}{l}\text { determine where } \\
\text { students are on the } \\
\text { continuum }\end{array}$ & teach collaborative skills \\
\hline
\end{tabular}


The principles may be aligned within four objectives which provide the structure for the curriculum: the instructor's role; characteristics of collaborative activities; preparation of students and incorporating differences. Table 5 displays these objectives and coincident principles.

Table 5

Curriculum Objectives and Principles

\begin{tabular}{|l|l|l|l|}
\hline \multicolumn{1}{|c|}{$\begin{array}{c}\text { Instructor's } \\
\text { Role }\end{array}$} & $\begin{array}{l}\text { Collaborative } \\
\text { Activities }\end{array}$ & \multicolumn{1}{|c|}{$\begin{array}{c}\text { Preparing } \\
\text { Students }\end{array}$} & $\begin{array}{l}\text { Incorporating } \\
\text { Differences }\end{array}$ \\
\hline $\begin{array}{l}\text { Explore own } \\
\text { assumptions }\end{array}$ & $\begin{array}{l}\text { Depend upon } \\
\text { interaction }\end{array}$ & $\begin{array}{l}\text { Teach social } \\
\text { and } \\
\text { collaborative } \\
\text { skills }\end{array}$ & $\begin{array}{l}\text { Create } \\
\text { safe/trusting } \\
\text { environment }\end{array}$ \\
\hline $\begin{array}{l}\text { Evaluate } \\
\text { content }\end{array}$ & $\begin{array}{l}\text { Use of } \\
\text { reflection }\end{array}$ & $\begin{array}{l}\text { Explore } \\
\text { assumptions }\end{array}$ & $\begin{array}{l}\text { Insure } \\
\text { everyone has } \\
\text { a voice }\end{array}$ \\
\hline $\begin{array}{l}\text { Model } \\
\text { collaborative } \\
\text { behaviors }\end{array}$ & $\begin{array}{l}\text { Insure } \\
\text { feedback }\end{array}$ & $\begin{array}{l}\text { Determine } \\
\text { where they } \\
\text { are on the } \\
\text { continuum }\end{array}$ & \\
\hline $\begin{array}{l}\text { Accept } \\
\text { ambiguity }\end{array}$ & & & \\
\hline $\begin{array}{l}\text { Intense pre- } \\
\text { planning }\end{array}$ & & & \\
\hline
\end{tabular}

Through the literature and the faculty interviews ideas for the curriculum have developed. The collaborative environment instructors 
create must be safe, encourage everyone to contribute and allow reflection. Instructors need to know how to build that environment, how to design activities leading to effective collaboration and how to prepare students to be effective collaborators.

\section{Limitations of Collaborative Learning}

The benefits of collaborative learning discussed in Chapter II and the emphasis of it value need a word of caution. Several of the faculty indicated that not every course is appropriate for collaborative learning. Specifically mentioned as considerations were issues of time, space, and content.

The content of the course or its purpose may not lend itself to collaboration that results in the development of knowledge, which is the focus of this thesis. Bruffee (1993) distinguishes between foundational knowledge and non-foundational and specifies that collaborative learning is ideal for non-foundational in which there are no right answers. For those courses with the purpose of conveying an established body of knowledge, introductory statistics, for example, collaborative learning would not improve the students' learning.

On the other hand, courses with content for which there is no set answers, theology of the modern novel, for example, lend themselves particularly well to collaborative learning within which 
students work together to discuss and share insights and together develop knowledge. Courses like these can lead to rich results which have the potential to engage the teacher in the learning process at the same time.

Content must also be considered in terms of how much materials must be covered during the course. Collaborative learning, based on both the literature and the faculty interviewed, results in the content being explored in more depth and less breadth. The work is richer and knowledge more meaningful. However, if there is a requirement to cover a specific amount of content, then collaborative learning may not work.

Time is another factor which must be considered when making a decision about creating collaborative learning. Successful collaborative experiences depend upon an amount of time being dedicated to collaborative group work during the class. Consequently, the length of the class period must be long enough to allow some whole class activities as well as group work. A two or three hour class is ideal; a fifty minute class may not provide ample time for effective group work.

In addition to length of class, collaboration itself takes time as students work through concepts and generate meaning. Groups cannot be rushed or the results may lack the depth and richness 
which are one of collaborative learning's benefits. As one of the faculty said, students must have the time to "uncover the content."

Unfortunately for those of us who are strong supporters of collaborative learning, many classrooms are not structured to accommodate it. The traditional college lecture hall with bolted down seats in orderly rows, perhaps tiered, would be a detriment to collaborative groups. Classrooms may be too small or have no access to separate areas in which groups may effectively work. Other resources may also be essential to collaborative learning and their availability must be considered. Examples may be flip charts and markers, construction paper, overhead projectors or other needs linked to and required by the content.

Another factor or possible limitation to collaborative learning is the target audience. Instructors must consider the participants. Generally, the adult learner may gain more through experiential work which is possible through collaboration. However, there are those whose learning style necessitates more internal processing to make sense of the concepts. At the same time that the instructor and individual students may be striving to insure that all students have a voice, that may result in pressure on those with a different learning style. 
Other limitations may result from those environments in which students are not willing nor able to collaborate because of time and distance constraints. In the urban college, students may be traveling considerable distances and working full time which would prohibit availability for collaborative time outside the classroom.

While instructors may enthusiastically approach their course with collaboration in mind, there are factors to consider before deciding that collaborative learning is the best method. Issues of time, space, content, and the learners themselves must be examined. It is conceivable that a fully planned collaborative approach may have to be discarded if these factors do not lend themselves to collaboration, and this may not be known until the first day of the course. Flexibility is important.

\section{Program Objectives}

According to Caffarella (1994), "Program objectives provide clear statements of the anticipated results to be achieved through an educational program" (p. 100). The objectives come directly out of the program ideas and serve as the basis for the transfer of learning plans. Additionally, it is against these objectives that the program is measured for its success or failure. The principles discussed in the 
prior section, structured around the foundational categories become the focus for the program objectives.

The previously stated purpose of this study is the design of a curriculum for instructors in techniques for creating collaborative environments. The broadly stated goal of the course, then, would be "The goal of this curriculum is to prepare instructors to teach using collaborative learning methods." The objectives are what is expected to be achieved by the participants. Stated altogether, the program goal and objectives are:

The goal of this curriculum is to prepare instructors to teach using collaborative learning methods. Following the course, instructors will be able to:

- understand the requirements of the instructor in preparation for and in the process of collaborative learning activities;

- articulate characteristics of and be able to create effective collaborative activities;

- $\quad$ specify techniques for preparing students to work collaboratively which include group process skills; and,

- explore ways to incorporate differences in the collaborative environment. 
Transfer of Learning

The curriculum will be for naught if participants are not able to apply and use the knowledge and information conveyed through the course. With the teaching method for the curriculum focusing on the collaborative learning, participants practice as they learn. That is where the value of collaborative learning really shines. The practice of working together to develop, for example, warm-up exercises to help students learn group processes, results in participants actively working with the concepts discussed and embeds the principles at the same time they are practiced. That is what transfer of learning is all about, can participants apply what they have learned when they return to their own classrooms?

The principles of the collaborative learning environment including trust, development of relationships, conversation, reflection and incorporating differences are practiced throughout the program, insuring that participants experience and work with them thereby solidifying the transfer of learning.

In addition to opportunities to practice through actual collaboration, during the course, participants are asked to prepare periodic reflection papers in which they explore what and how they have learned through the collaborative experience. The literature 
(Bosworth, 1994; Gerlach, 1994; Lowry, Osman-Jouchouz, \& Cyr, 1994; Lyman, 1995) and all faculty interviewed (see Table 4) recommended some method to elicit reflections about the process from the participants. First, this helps instructors assess how well students are handling the group process aspects of the collaborative environment. Secondly, it may provide data to help the instructor know when the process has gone off course and needs redirection.

A third means of gauging the transfer of learning is the request for "one-minute papers" from the participants. These papers, instantaneously prepared at the close of a class session, provide participants an opportunity to anonymously communicate questions or concerns about any aspect of the course. Review of the "one-minute papers" helps the instructor refocus on information of importance to the participants.

Major contribution to the successful transfer of learning allows participants to explore the concepts through working with practical examples from their own teaching experiences. Several faculty mentioned the importance of connecting the collaboration to relevant aspects of the students' lives. For example, participants can design collaborative projects applicable to their discipline. These can be done as a part of a collaborative group or individually, though as always, collaboration is the ideal. 
Transfer of learning occurs through relevant practice and is assured through reflection and one-minute papers.

\section{Evaluating Effectiveness}

As mentioned in the last chapter, evaluating the effectiveness of the curriculum is an essential component contributing to the author's ability to offer it to colleges, training centers, and businesses. Those potentially interested in the program need the assurance that it will produce the results planned for.

Caffarella (1994) describes five approaches to evaluation: objectives-based review, systems evaluation, case study method, quasi-legal evaluation, professional or expert review and "levels of evaluation" review. For the purposes of this study, the objectivesbased review seems most applicable. Objectives-based reviews consider whether or not the objectives for participant learning have been met. Were the program to be adapted to a specific organization in which detailed follow up analysis could be conducted, other evaluation approaches may be appropriate.

Within the objectives-based review, collection techniques may include observations, interviews, written questionnaires and performance reviews among others. Most courses at the college level and those offered by training consultants are evaluated through a 
written questionnaire completed by participants at the last session of the course. Likewise, the curriculum being developed includes a draft for a written questionnaire such as this (Appendix B).

However, with most courses, to learn at its end that participants were not gaining the knowledge expected is too late for instructors to modify the material to insure the program success. Consequently, the curriculum to prepare instructors to teach using collaborative learning may be evaluated by the instructor through observations of the participants during the collaborative exercises. One-minute papers and periodic reflection papers are two "in-process" evaluation techniques which were also used as gauges of the transfer of learning discussed previously.

Caffarella (1994) suggests evaluation extend beyond assuring individual participants are able to apply the knowledge learned. Aspects not included in this study, but which may be significant at the implementation stage, are review of costs and efficiencies.

\section{Instructional Plans}

The instructional plans included in the proposed curriculum are modeled after the suggestions of Caffarella (1994). "They spell out the anticipated end product [learning objectives], the content, the 
instructional techniques, and the evaluation strategies that make up the instructional process" (p. 201).

Instructional plan content evolved directly from the literature and faculty and is expected to lead to achievement of the program objectives. Planning ahead for courses incorporating collaborative learning was mentioned by a number of the faculty as a necessary element to a successful course.

The curriculum development process of this study has at its foundation the interactive model proposed by Caffarella (1994). Steps completed as a part of the study included gaining the support of faculty, gathering and identifying program ideas, sorting and prioritizing those ideas, developing proposed program objectives and instructional plans which display transfer of learning and evaluation methods. Further work prior to course implementation will necessitate the finalization of program objectives, modification of instructional plans, scheduling, budget development, facilities and communicating the program to others. 


\section{CHAPTER V}

\section{DISCUSSION OF THE PROPOSED CURRICULUM}

Contributions from the faculty and ideas from the literature stimulated the content in the curriculum. The model shown in Chapter III indicates that the curriculum design evolved from a collection of program ideas, shifted through and selected by the author. This chapter presents the curriculum as a course proposal and expands upon its elements through discussion of the rationale for their inclusion. In the ideal, following the Caffarella (1994) model would include the further work of sharing the proposal and seeking input and modifications. As Caffarella said, "Developing educational programs is a cooperative rather than "operative" endeavor" (p. 23). This step will occur in further work, a potential follow-up study.

\section{Course Proposal}

Chapter IV articulates the development of the program objectives and suggests other components such as the transfer of learning and evaluation activities. The proposed course (Appendix D) includes a course description, objectives, participant evaluation activities, 
required texts, the instructional format, topics and their sequence of presentation. Once the course is finalized and scheduled, this would become the syllabus presented to participants during the first session.

\section{Instructional Plans}

Instructional plans take the curriculum one step further into the session by session plan (Appendix D). The plan is designed with the intent of providing as much practice in actual collaboration as is possible within a ten week course. The assumption is made that the more the participants collaborate, the better able they will be to model and apply those skills when teaching their own courses. During the faculty interviews, Faculty "E" said the "best way to learn is by doing."

As the plans indicate, the format for which they are designed is a traditional 10-week, one night a week, college level course. These plans could very well be modified to another structure. For example, the content, together with the experiential opportunities within course, could be restructured to a two or three day workshop, or to a half day workshop for those with some prior experience. The preliminary plans are one example of the potential course to be developed.

Each of the 10 instructional plans details the learning objectives for the session and the techniques used to accomplish them. Key points, estimated times, and evaluation methods are likewise included. 
The instructional plan format follows that recommended by Caffarella (1994). According to Caffarella, "The instructional plan should be used as a guide for how the instructor and the participants spend their time in the session, not as a document that dictates precisely what each person must do when" (p. 198).

\section{Evaluation Methods}

In the course proposal, participant evaluation activities are described and include time lines for submission and review. Assignments are spaced throughout the course and are designed to be progressively more advanced as participants gain more understanding, practice and knowledge of the principles. A key focus of the assignments is that two of the three require collaboration. This matches the findings in the literature that evaluation of the group process, the group's and the individual's success are important (Slavin, 1983; Johnson \& Johnson, 1986).

Periodic de-briefing, using reflection papers and several oneminute papers as well as group discussions, is included in the curriculum to insure that participants have an opportunity to explore the group processes and express any concerns or misunderstandings. The importance of reflecting was emphasized both in the literature 
(Bosworth, 1994; Gerlach, 1994; Lowry, Osman-Jouchouz, \& Cyr, 1994; Lyman, 1995) and in the faculty interviews.

Warm-up exercises are incorporated to help participants get to know one another, give voice to differences, and develop a sense of trust and safety. Collaborative groups are assigned to create and present a warm-up to the whole class to accentuate their value to opening communications. Activities like this were suggested by the faculty for the purposes mentioned above and to make it fun, an important ingredient for effective collaboration.

The second collaborative group assignment is to decide upon one component of the course around which to design a collaborative activity. The curriculum includes in-class and out-of class time for groups to work together on this assignment. Presentation of group designed collaborative activities and discussion of the collaboration process is scheduled for the final class session.

The third assignment involves completion of a paper adapting a course the individual participant teaches or may teach to the collaborative learning method. This meets the needs of those participants claiming to work better by themselves. The evaluation activity results are combined by the instructor to provide feedback to the participants. Feedback may or may not be in the form of a 
traditional grade, depending upon the context within which the program occurs.

\section{Collaborative Groups}

With few exceptions, activities within the course revolve around collaborative groups. Initially, the introductory process occurs through dyads. Then, in the warm-up exercises, group composition varies. These activities help participants get to know each other and develop an understanding of the skills necessary to a collaborative process. Additionally, each of these activities offers the instructor time to consider the participants and learn about who they are and what they bring to the class. From this information, the instructor must determine which approach to take for assignment to the groups which remaining together through the remainder of the class.

Once within their group, participants are provided numerous opportunities to work together, exploring ideas and building knowledge about the collaborative process. Discussing readings, brainstorming topics and developing group activities in class and out of class lead to the relationships and alliances which enhance collaborative learning. Participants learn from each other. Faculty "G" said that in collaboration, there is no problem with authority, all are learners. 
Conclusion

Collaborative learning is a teaching method which promises to actively engage learners in the development of their knowledge. For students in a collaborative learning environment, it can result in enhanced achievement and increased abilities to problem solve and work effectively with others. In the work place, most of us are required to collaborate with others, consequently, it makes sense to teach in ways which will encourage and improve those skills.

In this study, literature has been reviewed and discussed pointing out the benefits of collaboration, the demands on instructors, ways of evaluating collaborative work and dealing with differences, and limitations to collaborative learning. For the instructor interested in using collaborative learning in the classroom, however, there is no easy guideline nor consolidated resource.

The intent of this study was to create a course, using information from the literature and insights from practicing faculty, to help instructors understand the elements of a collaborative learning environment and practice skills needed to create them. The course proposal and instructional plans present this course to meet that need. 


\section{REFERENCES}

Adler, M.J. (1982). Paideia proposal: An educational manifesto New York: MacMillan Publishing Co, Inc.

Belenky, M.F., Clinchy, B.M., Goldberger, N.R., \& Tarule, J.M. (1986). Women's ways of knowing: The development of self, voice, and mind. New York: Basic Books.

Berlin, J., \& Vivion, M. (Eds.). (1992). Cultural studies in the English classroom. Portsmouth, NH: Boynton/Cook Publishers.

Billson, J.M. (1994). Group process in the college classroom: Building relationships for learning. In S. Kadel \& J.A. Keehner (Eds.), Collaborative learning: A sourcebook for higher education, vol. 2 (pp. 21-41). University Park, PA: National Center on Postsecondary Teaching, Learning, and Assessment (NCTLA).

Billson, J.M., \& Tiberius, R.G. (1991). Effective social arrangements for teaching and learning. In R.J. Menges \& M.D. Svinicki (Eds.), New directions for teaching and learning, no. 45, College teaching: From theory to practice (pp. 87-110). San Francisco: Jossey-Bass Publishers.

Bosworth, K. (1994). Developing collaborative skills in college students. In K. Bosworth \& S.J. Hamilton (Eds.), New directions for teaching and learning, no. 59. Collaborative learning: Underlying processes and effective techniques (pp.25-32) San Francisco: Jossey-Bass Publishers.

Bowers, C.A. (1993). Critical essays on education, modernity, and the recovery of the ecological imperative. New York: Teachers College Press.

Brandt, R. (1990). On cooperative learning: A conversation with Spencer Kagan. Educational Leadership. 47 (4), 8-11.

Brilhart, J.K., \& Galanes, G.J. (1995). Effective group discussion. Dubuque, IA: Brown \& Benchmark. 
Bruffee, K. (1993). Collaborative learning. Baltimore: Johns Hopkins University Press.

Bruffee, K. (1995, January). Sharing our toys: Cooperative learning versus collaborative learning. Change, 27(1), 12-18.

Caffarella, R.S. (1994). Planning programs for adult learners: A practical guide for educators, trainers and staff developers. San Francisco: Jossey-Bass Publishers.

Chickering, A.W., \& Gamson, Z.F. (Eds.). (1991). Applying the seven principles for good practice in undergraduate education. New directions for teaching and learning, no. 47. San Francisco: Jossey-Bass.

Christensen, C.R. (1991a). Premises and practices of discussion teaching. In C.R. Christensen, D.A. Gavin, \& A. Sweet (Eds.) Education for judgment: The artistry of discussion leadership (pp. 15-36). Boston: Harvard Business School Press.

Christensen, C.R. (1991b). Every student teaches and every teacher learns: The reciprocal gift of discussion teaching. In C.R. Christensen, D.A. Gavin, \& A. Sweet (Eds.) Education for judgment: The artistry of discussion leadership (pp. 99 - 122). Boston: Harvard Business School Press.

Christensen, C.R., Garvin, D.A., \& Sweet, A. (Eds.). (1991). Education for judgment: The artistry of discussion leadership. Boston: Harvard Business School Press.

Cohen, E. (1986). Designing group work: Strategies for the heterogeneous classroom. New York: Teachers College Press.

Condon, J.C. (1986). The ethnocentric classroom. In J.M. Civikly (Ed.), New directions for teaching and learning, no. 26, Communicating in college classrooms (pp. 11-20). San Francisco: Jossey-Bass Publishers.

Cooper, J.L., \& Mueck, R. (1992). Student involvement in learning: Cooperative learning and college instruction. In A.S. Goodsell, M.R. Maher, \& V. Tinto (Eds.), Collaborative learning: A sourcebook for higher education (pp. 68-74). University Park, PA: NCTLA. 
Downs, V.C., Javidi, M., \& Nussbaum, J.F. (1988, April). An analysis of teachers' verbal communication within the college classroom: Use of humor, self-disclosure, and narratives. Communication Education, 37(2), 127-141.

DuBois, C.C. (1992, September/October). Portrait of the ideal MBA. The Penn Stater, p. 31.

Fiechtner, S.B., \& Davis, E.A. (1992) Why some groups fail: A survey of students' experiences with learning groups. In A. Goodsell, $\mathrm{M}$. Maher, \& V. Tinto (Eds.), Collaborative learning: A sourcebook for higher education (pp. 59-67). University Park, PA: NCTLA.

Finkel, D.L., \& Monk, G.S. (1992). Teachers and learning groups: Dissolution of the atlas complex. In A. Goodsell, M. Maher, \& V. Tinto (Eds.), Collaborative learning: A sourcebook for higher education (pp. 50-58). University Park, PA: NCTLA.

Fordham, S. (1988). Racelessness as a factor in black students' school success: Pragmatic strategy or pyrrhic victory? In H.S. Shapiro \& D.E. Purpel (Eds.), Critical social issues in American education (pp. 149-178). White Plains, NY: Longman Publishing Group.

Freire, P., \& Macedo, D.P. (1995). A dialogue: Culture, language, and race. Harvard Educational Review, 65(3), 377-402.

Frierson, Jr., H.T. (1986). Two intervention methods: Effects on groups of predominantly black nursing students' board scores. Journal of Research and Development in Education, 19(3), 1823.

Furtwengler, C.B. (1995). Practical methods for assessing cooperative learning in higher education. In H.C. Foyle (Ed.), Interactive learning in the higher education classroom: Cooperative, collaborative and active learning strategies (pp. 148-159). Washington, DC: NEA.

Garvin, D.A. (1991). Barriers and gateways to learning. In C.R. Christensen, D.A. Garvin, \& A. Sweet (Eds.), Education for judgment: The artistry of discussion leadership (pp. 3-14). Boston: Harvard Business School Press. 
Gerlach, J.M. (1994). Is this collaboration? In K. Bosworth, S.J. Hamilton (Eds.), New directions for teaching and learning, No 59. Collaborative learning: Underlying processes and effective techniques (pp. 5-14). San Francisco: Jossey-Bass.

Goodsell, A., Maher, M., \& Tinto, V. (1992). Collaborative learning: A sourcebook for higher education. University Park, PA: NCTLA.

Hall, J. (1971, November). Decisions, decisions, decisions. Psychology Today, $5(6), 51-86$.

Hamilton, S.J. (1994). Freedom transformed: Toward a developmental model for the construction of collaborative learning environments. In K. Bosworth, \& S.J. Hamilton (Eds.), New directions for teaching and learning, no. 59, Collaborative learning: Underlying processes and effective techniques (pp.93102). San Francisco: Jossey-Bass Publishers.

Haring-Smith, T. (1993). Learning together: An introduction to collaborative learning. New York: Harper Collins College Publishers.

Haring-Smith, T. (1995). Why collaborative learning backfires. What works: Building effective collaborative learning experiences $\mathrm{pp}$. 337-341. University Park, PA: NCTLA.

Hertz-Lazarowitz, R., \& Shachar, H. (1990). Teachers' verbal behavior in cooperative and whole-class instruction. In S. Sharan (Ed.), Cooperative learning: Theory and practice (pp. 77-94). New York: Praeger Publishers.

hooks, b. (1994). Teaching to transgress. New York: Routledge.

Johnson, D.W., \& Johnson, R.T. (1979). Conflict in the classroom: Controversy and learning. Review of Educational Research. 49(1), 51-70.

Johnson, D.W., \& Johnson, R.T. (1984). Cooperative small-group learning. Curriculum report 14(1), National Association of Secondary School Principals. Reston, VA.

Johnson, D.W., \& Johnson, R.T. (1986). Circles of learning:

Cooperation in the classroom. Edna, MN: Interaction Book Co. 
Johnson, D.W., \& Johnson, R.T. (1987a). Learning together and alone: Cooperative, competitive and individualistic learning (2nd ed.). Englewood Cliffs, NJ: Prentice-Hall.

Johnson, D.W., \& Johnson, R.T. (1987b). Research shows the benefits of adult cooperation. Educational Leadership, 45(3), 27-30.

Johnson, D.W., \& Johnson, R.T. (1989). Cooperation and competition: Theory and resarch. Edina, MN: Interaction Book Company.

Johnson, D.W., \& Johnson, R.T. (1990). Cooperative learning and achievement. In S. Sharan (Ed.), Cooperative learning: Theory and research (pp. 23-37). New York: Praeger Publishers.

Johnson, D.W., Johnson, R.T., \& Skon, L. (1979). Student achievement on different types of tasks under cooperative, competitive, and individualistic conditions. Contemporary Educational Psychology, 4(2), 99-106.

Johnson, D.W., Johnson, R.T., \& Smith, K.A. (1991) Cooperative Learning: Increasing college faculty instructional productivity. Washington, DC: School of Education and Human Development, George Washington University.

Johnson, R.T., \& Johnson, D.W. (1983). Effects of cooperative, competitive, and individualistic learning experiences on social development. Exceptional Children, 49(4), 323-330.

Johnson, D.W., Maruyama, G., Johnson, R., Nelson, D., \& Skon, L. (1981). Effects of cooperative, competitive, and individualistic goal structures on achievement: A meta-analysis. Psychological Bulletin, 89(1), 47-62.

Kadel, S., \& Keehner, J.A. (Eds.). (1994). Collaborative learning: A sourcebook for higher education, vol 2. University Park, PA: NCTLA.

Katz, J., \& Henry, M. (1988). Turning professors into teachers: A new approach to faculty development and student learning. New York: American Council on Education/Macmillan. 
Lazarowitz, R., \& Karsenty, G. (1990). Coooperative learning and students' academic achievement, process skills, learning environment, and self esteem in tenth-grade biology classrooms. In S. Sharan (Ed.), Cooperative learning: Theory and research (pp.123-149). New York: Praeger Publishers.

Lee, C.D., Lomotey, K., \& Shujaa, M. (1990). How shall we sing our sacred song in a strange land? The dilemma of double consciousness and the complexities of an African-centered pedagogy. In H.S. Shapiro, \& D.E. Purpel (Eds.), Critical social issues in American education (pp. 179-193). White Plains, NY: Longman Publishing Group.

Liden, R.C., Wayne, S.J., \& Bradway, L. (1996, February).

Connections make the difference. HRMagazine, 41(2), 73-79.

Lowry, M., Osman-Jouchouz, R., \& Cyr, T. (1994, February 16-20). Collaboration as an instructional innovation. Paper presented at the National Convention of the Association for Educational Communications and Technology Division, Nashville, TN. (ERIC Document Reproduction Service No. ED 373 737)

Lyman, L. (1995). Group building in the college classroom. In H.C. Foyle (Ed.), Interactive learning in the higher education classroom: Cooperative, collaborative and active learning strategies (pp. 177-191). Washington, DC:NEA.

MacGregor, J.T. (1992). Collaborative learning: Reframing the classroom. In A.S. Goodsell, M.R. Maher, \& V. Tinto (Eds.), Collaborative learning: A sourcebook for higher education (pp. 37-40). University Park, PA: NCTLA.

Miller, J.E., Trimbur, J., \& Wilkes, J.M. (1994). Group dynamics: Understanding groups success and failure in collaborative learning. In K. Bosworth \& S.J. Hamilton (Eds.), New directions for teaching and learning, no. 59. Collaborative learning: Underlying processes and effective techniques (pp. 33-44). San Francisco: Jossey-Bass Publishers.

Miller, N., \& Harrington, H.J. (1990). A situational identity perspective on cultural diversity and teamwork in the classroom. In S. Sharan (Ed.), Cooperative learning: Theory and research (pp. 3976). New York: Praeger Publishers. 
Nelson, C.E. (1994). Critical thinking and collaborative learning. In K. Bosworth \& S.J. Hamilton (Eds.), New directions for teaching and learning, no. 59. Collaborative learning: Underlying processes and effective techniques (pp.45-58). San Francisco: Jossey-Bass Publishers.

Qin, Z., Johnson, D.W., \& Johnson, R.T. (1995). Cooperative versus competitive efforts and problem solving. In Review of Educational Research, 65(2), 129-143.

Romer, K.T., \& Whipple, W.R. (1991). Collaboration across the power line. College Teaching, 39(2), 66-70.

Schriner, D.R. (1992). One person, many worlds: A multi-cultural composition curriculum. In J.A. Berlin \& M.J. Vivion (Eds.), Cultural studies in the English classroom (pp. 95-111). Portsmouth, NH: Boynton/Cook Publishers, Inc.

Sharan, S (Ed.). (1990). Cooperative learning: Theory, and research. New York: Praeger.

Sheridan, J., Byrne, A.C., \& Quina, K. (1989). Collaborative learning: Notes from the field. College Teaching, 37(2), 49-53.

Slavin, R.E. (1983). When does cooperative learning increase student achievement? Psychological Bulletin, 94(3), 429-445.

Slavin, R.E. (1990). Cooperative learning: Theory, research, and practice. Englewood Cliffs, NJ: Prentice-Hall.

Smith, B.L., \& MacGregor, J.T. (1992). What is collaborative Learing? In A. Goodsell, M. Maher, \& V. Tinto (Eds.), Collaborative learning: A sourcebook for higher education (pp. 9-22). University Park, PA: NCTLA.

Svinicki, M.D.(1991) Practical implications of cognitive theories. In R.J. Menges \& M.D. Svinicki (Eds.), New directions for teaching and learning, no. 45, College teaching from theory to practice (pp. 27-38). San Francisco: Jossey-Bass, Inc. 
Tiberius, R.G., \& Billson, J.M. (1991). The social context of teaching and learning. In R.J. Menges \& M.D. Svinicki (Eds.), New directions for teaching and learning, no. 45, College teaching from theory to practice (pp. 67-86). San Francisco: Jossey-Bass, Inc.

Trimbur, J. (1993). Consensus and difference in collaborative learning. College English, 51(6), 602-616.

Wiener, H.S. (1986). Collaborative learning in the classroom: A guide to evaluation. College English, 48(1), 52-61.

Whipple, W.R. (1987, October). Collaborative learning: Recognizing it when we see it. AAHE Bulletin, 3-6. 
APPENDIX A

\section{INTERVIEW GUIDE}


Faculty Interviewed

Date

\section{CREATING COLLABORATIVE LEARNING ENVIRONMENTS: A CURRICULUM FOR INSTRUCTORS}

The purpose of my thesis is to design a curriculum for instructors seeking ways to effectively create collaborative environments within the classroom. I have defined collaborative learning within my study to encompass team learning activities in the college classroom which engage students in the development of knowledge through interacting as a part of a group to investigate questions and explore, develop and pose answers.

Although I have conducted a thorough review of literature about collaborative learning, I believe that the curriculum I develop will be strengthened through the contributions and actual experiences of faculty members who attempted, successfully and perhaps unsuccessfully, to create collaborative environments. Hence, this interview.

What are your experiences with collaborative learning?

What are the characteristics of an effective collaborative learning environment?

What challenges have you faced in creating collaborative learning experiences and how have you dealt with them? 
What are the skills you believe are essential for instructors creating collaborative environments?

In what way have cultural differences within groups impacted the creation of the collaborative environment?

And, how have you factored these differences into your collaborative efforts?

What impact does creating collaborative experiences have on course content?

What advice would you give to other faculty interested in using collaborative learning in the classroom? 
APPENDIX B

PARTICIPANT COURSE EVALUATION QUESTIONNAIRE (DRAFT) 


\section{DRAFT \\ COURSE EVALUATION QUESTIONNAIRE \\ CREATING COLLABORATIVE LEARNING ENVIRONMENTS}

Your Name:

Date:

(Optional)

The goal of the course has been to prepare you to teach using collaborative learning methods. The instructors of this course want to be sure that the goal has been met and that participants are able to use the information presented and concepts practiced. To help provide information about the effectiveness of the course in meeting the goal, please take the time to complete this questionnaire about your experiences in the course.

\begin{tabular}{|c|c|c|}
\hline Part 1 & Content & NO $\gg>\gg>>Y E S$ \\
\hline 1. & $\begin{array}{l}\text { Course objectives were clear } \\
\text { Comments: }\end{array}$ & 12345 \\
\hline 2. & $\begin{array}{l}\text { Content supported objectives } \\
\text { Comments: }\end{array}$ & 12345 \\
\hline 3. & $\begin{array}{l}\text { Activities provided practice } \\
\text { Comments: }\end{array}$ & 12345 \\
\hline 4. & $\begin{array}{l}\text { Given the stated objectives, you learned what you planned } \\
\text { Comments: }\end{array}$ & 12345 \\
\hline
\end{tabular}

6. What did not work for you? Comments:

Part 2. Instructor Skills

1. The instructor was prepared Comments:

2. The instructor knew the content Comments:

3. The instructor's approach facilitated learning Comments:

12345

12345

12345 
4. What suggestions would you make to improve the instruction? Comments:

Part 3. Overall Course Evaluation

\begin{tabular}{l|l|l|}
\hline 1. $\quad$ You are able to apply the concepts & 12345 \\
\hline $2 . \quad$ The course was a stimulating way to learn & \begin{tabular}{l}
1234 \\
\hline $3 . \quad$ The course was terrific
\end{tabular} \\
\hline
\end{tabular}

4. The best part of the course was:

5. The worst part of the course was:

6. Please provide other comments:

THANK YOU FOR YOUR HELP 
APPENDIX C

COURSE PROPOSAL 
COURSE PROPOSAL

\section{CREATING COLLABORATIVE LEARNING ENVIRONMENTS}

\section{Course Description:}

The goal of this course is to prepare participants to teach using collaborative learning methods. With a focus on college level or business training rooms, the course covers the ins and outs of designing and presenting a course with collaborative learning as the primary teaching method. Includes exploration of influences on course content, evaluation activities, role of the instructor in the classroom, and encouraging effective collaborative work.

Objectives:

Following the course, participants will be able to:

- Understand the requirements of the instructor in preparation for and in the process of collaborative learning activities;

- Articulate characteristics of and be able to create effective collaborative activities;

- Specify techniques for preparing students to work collaboratively which include group process skills;

- Explore and apply ways to incorporate differences in the collaborative environment.

\section{Participant Evaluation Activities:}

Participation level/contribution to the class and the assigned group.

Collaboratively created "warm-up" exercise.

Collaboratively created project designing a collaborative activity.

Individual paper adapting a course to the collaborative learning method.

Three brief reflection papers on the collaborative process of the group.

\section{Required Texts:}

K. Bosworth \& S.J. Hamilton (Eds.). (1994). New Directions for Teaching and Learning, No. 59. Collaborative Learning: Underlying Processes and Effective Techniques. San Francisco, CA.: Jossey-Bass Publishers.

A.S. Goodsell, M.R. Maher \& V. Tinto (Eds.). (1992). Collaborative Learning: A Sourcebook for Higher Education. University Park, PA: NCTLA.

A packet of selected readings will also be required.

Instructional Format:

The class will meet one day per week during the ten week term. Each class session will be two and one half hours long. 
Week One

Week Two

Week Three

Week Four

Week Five

Week Six

Week Seven

Week Eight

Week Nine

Week Ten
Introductions/Overview of Course

Establishing Ground Rules

Exploring the Instructor's Role

Planning Ahead

Group Processes

Group Roles

First Reflection Paper due

Structure of Collaborative Activities

Group Presentations of Warm-up Exercises

Influence of Collaborative Learning on Content

Collaborative learning is not always the answer

Group Presentations of Warm-up Exercises

Instructor as Facilitator

Second Reflection Paper due

All Kinds of Differences

Diversity in the Collaborative Environment

Making Collaboration Fun

Creating a Trusting, Safe Environment

Wrapping it up

Ways to Engage Students in Discussing Process

Third Reflection Paper due

Group presentations of Collaborative Activity

Individual Paper due

Assignments:

Group Warm-up Exercise. Each group creates a brief activity to introduce students to group processes and build connections and relationships within the groups. These 15 minute exercises will be presented to the class who will be the participants. Groups will present the warm-ups during the fourth and fifth week of the course.

Group Collaborative Project. Each group will select a component of the course content and design a collaborative activity. Groups will present the activity to the class and discuss the process of collaboration during the final session.

Individual Paper. Participants will adapt a course to be taught using collaborative learning as the teaching method. The paper will be turned in at the final session. 
APPENDIX D

INSTRUCTIONAL PLANS 


\section{CREATING COLLABORATIVE LEARNING ENVIRONMENTS}

\section{INSTRUCTIONAL PLAN - WEEK ONE}

Introductions

Learning Objectives:

\begin{tabular}{l|l|l|l|l}
\hline $\begin{array}{l}\text { Participants will be } \\
\text { able to.. }\end{array}$ & Content Heading & \multicolumn{1}{|c|}{ Key Points } & Instructional Techniques & Time \\
\hline Get to know class members & Introductions & $\begin{array}{l}\text { One element of Collaborative Learning } \\
\text { is the development of relationships }\end{array}$ & $\begin{array}{l}\text { Members will partner in dyads and } \\
\text { create a two minute life story to } \\
\text { share with the class }\end{array}$ & $\begin{array}{l}\text { Instructor will walk through the } \\
\text { syllabus }\end{array}$ \\
\hline $\begin{array}{l}\text { State the objectives of the } \\
\text { course }\end{array}$ & Overview of the Course & $\begin{array}{l}\text { Because one major need for teachers in } \\
\text { collaborative environments is to be } \\
\text { flexible, elements may change }\end{array}$ & $\begin{array}{l}\text { Getting to know people in fun ways } \\
\text { increases learning }\end{array}$ & Small-group exercise \\
\hline $\begin{array}{l}\text { Understand warm-ups as a } \\
\text { way to create safe } \\
\text { collaborative environments }\end{array}$ & Warm-up Exercise \\
\hline $\begin{array}{l}\text { Explain the value of ground } \\
\text { rules to an effective group }\end{array}$ & $\begin{array}{l}\text { Establishing ground } \\
\text { nules }\end{array}$ & $\begin{array}{l}\text { Ground rules help keep the process on } \\
\text { track and create a safe environment }\end{array}$ & $\begin{array}{l}\text { Whole group brainstorming; } \\
\text { Mini-lecture while narrowing } \\
\text { down the ideas }\end{array}$ \\
\hline $\begin{array}{l}\text { Reflect about and share } \\
\text { feedback of session }\end{array}$ & De-brief the session & $\begin{array}{l}\text { Reflecting on the process of } \\
\text { collaboration contributes to its success }\end{array}$ & $\begin{array}{l}\text { Whole group discussion; } \\
\text { completion of one minute papers }\end{array}$ & 20 min. \\
\hline
\end{tabular}

\section{Assignment: $\quad$ Readings on the instructor's role.}

Evaluation plan: Review of the brain stormed ideas. Analysis of warm-up, ground rules and the one minute papers. 


\section{CREATING COLLABORATIVE LEARNING ENVIRONMENTS}

\section{INSTRUCTIONAL PLAN - WEEK TWO}

The Instructor's Role

Learning Objectives:

\begin{tabular}{|c|c|c|c|c|}
\hline $\begin{array}{c}\text { Participants will be } \\
\text { able to.. }\end{array}$ & Content Heading & Key Points & Instructional Techniques & Time \\
\hline $\begin{array}{l}\text { Experience various ways to } \\
\text { get to know others }\end{array}$ & Warm-up exercises & $\begin{array}{l}\text { Exploring a variety of ways to get to } \\
\text { know people }\end{array}$ & $\begin{array}{l}\text { Warm-up exercises in small } \\
\text { groups }\end{array}$ & $30 \mathrm{~min}$. \\
\hline $\begin{array}{l}\text { Describe at least three } \\
\text { ways groups may be } \\
\text { formed }\end{array}$ & Forming groups & $\begin{array}{l}\text { Groups may be formed by similar } \\
\text { characteristics or dissimilar, randomly } \\
\text { or with purpose }\end{array}$ & $\begin{array}{l}\text { Active exercise sorting the class } \\
\text { into groups based upon varied } \\
\text { criteria }\end{array}$ & $30 \mathrm{~min}$. \\
\hline $\begin{array}{l}\text { Explain and discuss the } \\
\text { instructor's role in } \\
\text { collaboration }\end{array}$ & $\begin{array}{l}\text { Brainstorming the } \\
\text { instructor's role }\end{array}$ & $\begin{array}{l}\text { The role has more demands before the } \\
\text { class but provides the luxury of } \\
\text { observation during the class }\end{array}$ & $\begin{array}{l}\text { Using the last group configuration } \\
\text { from above, groups brainstorm } \\
\text { ideas }\end{array}$ & $30 \mathrm{~min}$. \\
\hline $\begin{array}{l}\text { Be part of a group during } \\
\text { the course }\end{array}$ & Assignment into groups & $\begin{array}{l}\text { The instructor has the final obligation } \\
\text { to determine the basis for group } \\
\text { assignment }\end{array}$ & & $20 \mathrm{~min}$ \\
\hline $\begin{array}{l}\text { Define instructor's need to } \\
\text { plan ahead }\end{array}$ & $\begin{array}{l}\text { Collaborative learning } \\
\text { takes planning }\end{array}$ & $\begin{array}{l}\text { Demands for planning for the } \\
\text { collaborative environment is intense }\end{array}$ & $\begin{array}{l}\text { Mini-lecture followed by } \\
\text { participant contributions }\end{array}$ & $25 \mathrm{~min}$ \\
\hline Experience group work & Time to work in groups & $\begin{array}{l}\text { Begin defining yourselves; groups } \\
\text { decide upon a name }\end{array}$ & Group work & $15 \mathrm{~min}$ \\
\hline
\end{tabular}

Assignment:

Readings on group processes, first reflection paper due next session

Evaluation Plan: $\quad$ Analysis of ability of groups to select a name, review of brainstorming ideas on instructor's role. 


\section{CREATING COLLABORATIVE LEARNING ENVIRONMENTS}

\section{INSTRUCTIONAL PLAN - WEEK THREE \\ Group Processes}

Learning Objectives:

\begin{tabular}{|c|c|c|c|c|}
\hline $\begin{array}{l}\text { Participants will be } \\
\text { able to.. }\end{array}$ & Content Heading & Key Points & Instructional Techniques & Time \\
\hline $\begin{array}{l}\text { Explain the importance of } \\
\text { effective group processes }\end{array}$ & $\begin{array}{l}\text { What makes a good } \\
\text { group? }\end{array}$ & $\begin{array}{l}\text { Good groups may not always be the } \\
\text { ones which appear to be the most } \\
\text { harmonious }\end{array}$ & $\begin{array}{l}\text { Group brainstorming; reporting } \\
\text { out on results }\end{array}$ & $45 \mathrm{~min}$. \\
\hline $\begin{array}{l}\text { State the importance of } \\
\text { teaching students group } \\
\text { processes }\end{array}$ & $\begin{array}{l}\text { Groups and } \\
\text { collaboration }\end{array}$ & $\begin{array}{l}\text { If students don't understand what is } \\
\text { going on in the way a group works, the } \\
\text { collaboration may flounder. }\end{array}$ & Mini-lecture and open discussion & $30 \mathrm{~min}$. \\
\hline $\begin{array}{l}\text { Plan for group warm-up } \\
\text { exercises }\end{array}$ & $\begin{array}{l}\text { Scheduling group } \\
\text { presentations }\end{array}$ & & $\begin{array}{l}\text { Groups self-select date and time } \\
\text { slot for presentation }\end{array}$ & $10 \mathrm{~min}$. \\
\hline $\begin{array}{l}\text { Classify role of group } \\
\text { members }\end{array}$ & Roles found in groups & $\begin{array}{l}\text { Most groups find that specific roles } \\
\text { develop, whether assigned or natural. } \\
\text { These can help the collaborative } \\
\text { process but should not restrict it. }\end{array}$ & $\begin{array}{l}\text { Mini-lecture followed by } \\
\text { participant contributions }\end{array}$ & $30 \mathrm{~min}$ \\
\hline $\begin{array}{l}\text { Experience a group in } \\
\text { action }\end{array}$ & $\begin{array}{l}\text { Collaborative group } \\
\text { time }\end{array}$ & $\begin{array}{l}\text { Groups are charged with developing an } \\
\text { effective warm-up exercise for } \\
\text { presentation to the whole class }\end{array}$ & Group work & $30 \mathrm{~min}$. \\
\hline
\end{tabular}

Assignment: First reflection paper due this session. Readings on structure of collaborative activities.

Evaluation Plan: Analysis of brainstorming ideas generated. Review of first reflection paper submitted. 
Learning Objectives:

\section{CREATING COLLABORATIVE LEARNING ENVIRONMENTS \\ INSTRUCTIONAL PLAN - WEEK FOUR \\ Structure of Collaborative Activities}

\begin{tabular}{|c|c|c|c|c|}
\hline $\begin{array}{l}\text { Participants will be } \\
\text { able to.. }\end{array}$ & Content Heading & Key Points & Instructional Techniques & Time \\
\hline $\begin{array}{l}\text { Evaluate effectiveness of } \\
\text { warm-up activities }\end{array}$ & $\begin{array}{l}\text { Presentation of first } \\
\text { group's warm-up } \\
\text { exercise }\end{array}$ & $\begin{array}{l}\text { De-brief with questions: Did the warm- } \\
\text { up create new awareness about others? } \\
\text { Was it fun? Was it respectful of all? } \\
\text { Did it require working together. }\end{array}$ & $\begin{array}{l}\text { First group leads the warm-up and } \\
\text { the de-briefing and reports on the } \\
\text { collaborative process }\end{array}$ & $30 \mathrm{Min}$. \\
\hline $\begin{array}{l}\text { Identify qualities of } \\
\text { collaborative activities }\end{array}$ & Collaborative Activities & $\begin{array}{l}\text { Clearly articulate desired end result, } \\
\text { with the details remaining to the group. } \\
\text { Insure members must work together. } \\
\text { Allow ample time. }\end{array}$ & $\begin{array}{l}\text { Group brainstorming and } \\
\text { reporting out to the whole }\end{array}$ & $45 \mathrm{~min}$. \\
\hline $\begin{array}{l}\text { Evaluate the influence on } \\
\text { content when using } \\
\text { collaborative learning }\end{array}$ & $\begin{array}{l}\text { Content and } \\
\text { collaborative learning }\end{array}$ & $\begin{array}{l}\text { Collaborative learning can result in } \\
\text { content being explored in more depth } \\
\text { but less breadth. }\end{array}$ & Mini-lecture and group discussion & $30 \mathrm{~min}$. \\
\hline $\begin{array}{l}\text { Compare and contrast } \\
\text { effectiveness of warm-up } \\
\text { activities }\end{array}$ & $\begin{array}{l}\text { Presentation of second } \\
\text { group's warm-up } \\
\text { exercise }\end{array}$ & De-brief with questions from above. & $\begin{array}{l}\text { Second group leads the warm-up } \\
\text { and the de-briefing and reports on } \\
\text { the collaborative process }\end{array}$ & $30 \mathrm{~min}$. \\
\hline $\begin{array}{l}\text { Understand the second } \\
\text { group assignment }\end{array}$ & Discuss group project & $\begin{array}{l}\text { Select one of the principle components } \\
\text { of the course outline and design a } \\
\text { collaborative activity which will } \\
\text { uncover the principles }\end{array}$ & $\begin{array}{l}\text { Presentation by instructor } \\
\text { followed by question and answer }\end{array}$ & $15 \mathrm{~min}$ \\
\hline & \multicolumn{4}{|c|}{$\begin{array}{l}\text { Complete one minute paper at the end of this session. Readings on when collaborative learning is an } \\
\text { appropriate teaching method. }\end{array}$} \\
\hline Evaluation Plan: & \multicolumn{4}{|c|}{ Review and evaluation of presented warm-up exercises, review of one minute papers. } \\
\hline
\end{tabular}




\section{CREATING COLLABORATIVE LEARNING ENVIRONMENTS}

\section{INSTRUCTIONAL PLAN - WEEK FIVE}

More on Collaborative Activities

Learning Objectives:

\begin{tabular}{l|l|l|l|l}
\hline $\begin{array}{c}\text { Participants will be } \\
\text { able to.. }\end{array}$ & \multicolumn{1}{|c|}{ Content Heading } & \multicolumn{1}{c|}{ Key Points } & Instructional Techniques & Time \\
\hline $\begin{array}{l}\text { Participate in group } \\
\text { designed warm-up. }\end{array}$ & $\begin{array}{l}\text { Presentation of third } \\
\text { group's warm-up } \\
\text { exercise }\end{array}$ & $\begin{array}{l}\text { De-brief with questions from last } \\
\text { session. }\end{array}$ & $\begin{array}{l}\text { Third group leads the warm-up } \\
\text { and the de-briefing and reports on } \\
\text { the collaborative process }\end{array}$ & 30 min. \\
\hline $\begin{array}{l}\text { Identify situations in which } \\
\text { collaborative learning may } \\
\text { not work }\end{array}$ & $\begin{array}{l}\text { Collaborative learning } \\
\text { is not the answer to } \\
\text { every thing }\end{array}$ & $\begin{array}{l}\text { Important to evaluate content, } \\
\text { resources, time and logistics before } \\
\text { deciding to use collaborative learning }\end{array}$ & Mini-lecture and group discussion \\
\hline $\begin{array}{l}\text { Participate in another } \\
\text { group warm-up }\end{array}$ & $\begin{array}{l}\text { Presentation of fourth } \\
\text { group's warm-up } \\
\text { exercise }\end{array}$ & $\begin{array}{l}\text { De-brief with questions: Did the warm- } \\
\text { up create new awareness about others? } \\
\text { Was it fun? Was it respectful of all? } \\
\text { Did it require working together. }\end{array}$ & $\begin{array}{l}\text { Fourth group leads the warm-up } \\
\text { and the de-briefing and reports on } \\
\text { the collaborative process }\end{array}$ & 30 min. \\
\hline $\begin{array}{l}\text { Explain the three types of } \\
\text { evaluation of collaborative } \\
\text { activities }\end{array}$ & $\begin{array}{l}\text { Evaluating } \\
\text { collaboration }\end{array}$ & $\begin{array}{l}\text { The results produced by the group, the } \\
\text { individual accomplishment and the } \\
\text { success of the collaborative process are } \\
\text { all important. }\end{array}$ & Mini-lecture and group discussion \\
\hline Work as a group & $\begin{array}{l}\text { Collaborative group } \\
\text { time }\end{array}$ & $\begin{array}{l}\text { Time for groups to begin thinking } \\
\text { about second project or complete } \\
\text { warm-up exercise }\end{array}$ & Group work \\
\hline
\end{tabular}

Assignment: $\quad$ Reminder that second reflection paper is due next session. Readings on instructor as facilitator.

Evaluation Plan: Review and evaluation of presented warm-up exercises. 


\section{CREATING COLLABORATIVE LEARNING ENVIRONMENTS}

\section{INSTRUCTIONAL PLAN - WEEK SIX}

Instructor as Facilitator

Learning Objectives:

\begin{tabular}{l|l|l|l|l}
\hline $\begin{array}{c}\text { Participants will be } \\
\text { able to.. }\end{array}$ & \multicolumn{1}{|c|}{ Content Heading } & \multicolumn{1}{c|}{ Key Points } & Instructional Techniques & Time \\
\hline Reflect on prior sessions & What we have learned & $\begin{array}{l}\text { Are participants grasping the } \\
\text { concepts and beginning to work } \\
\text { with the principles? }\end{array}$ & $\begin{array}{l}\text { Whole group discussion } \\
\text { facilitated by instructor }\end{array}$ & 30 min. \\
\hline $\begin{array}{l}\text { Explain the instructor's } \\
\text { role during the } \\
\text { collaborative learning } \\
\text { process }\end{array}$ & $\begin{array}{l}\text { Instructor as } \\
\text { facilitator }\end{array}$ & $\begin{array}{l}\text { Modeling the communications and } \\
\text { collaboration. Balancing the } \\
\text { responsibility to guide with the urge } \\
\text { to the authority. }\end{array}$ & $\begin{array}{l}\text { Mini-lecture and group } \\
\text { discussion }\end{array}$ & 30 min. \\
\hline $\begin{array}{l}\text { Generate ideas about the } \\
\text { instructor's role }\end{array}$ & $\begin{array}{l}\text { Group brainstorming } \\
\text { about the instructor's } \\
\text { role }\end{array}$ & $\begin{array}{l}\text { Group generated examples of } \\
\text { facilitative, managerial roles. }\end{array}$ & $\begin{array}{l}\text { Group brainstorming and } \\
\text { reporting out to the whole } \\
\text { group }\end{array}$ & 30 min. \\
\hline Work as a group & $\begin{array}{l}\text { Collaborative group } \\
\text { time }\end{array}$ & $\begin{array}{l}\text { Time for groups to work on second } \\
\text { project. }\end{array}$ & Group work \\
\hline
\end{tabular}

Assignment: Second reflection paper due this session. Readings on diversity in the collaborative environment.

Evaluation Plan: Review and evaluation of reflection discussion and papers. Participation in group discussions. 


\section{CREATING COLLABORATIVE LEARNING ENVIRONMENTS}

\section{INSTRUCTIONAL PLAN - WEEK SEVEN \\ All Kinds of Differences}

Learning Objectives:

\begin{tabular}{l|l|l|l|l}
\hline $\begin{array}{c}\text { Participants will be } \\
\text { able to.. }\end{array}$ & Content Heading & \multicolumn{1}{c|}{ Key Points } & Instructional Techniques & \multicolumn{1}{c}{ Time } \\
\hline $\begin{array}{l}\text { Describe "difference" } \\
\text { What do we really mean } \\
\text { by different? }\end{array}$ & $\begin{array}{l}\text { Cultural differences may be more or } \\
\text { less obvious. Tendency to conclude } \\
\text { that if they look like me they must be } \\
\text { like me; ignores significant difference } \\
\text { which impacts group work }\end{array}$ & $\begin{array}{l}\text { Mini-lecture and whole group } \\
\text { discussion }\end{array}$ & 30 min. \\
\hline $\begin{array}{l}\text { Understand the ways in } \\
\text { which they may be }\end{array}$ & Learning about variety & $\begin{array}{l}\text { Communication styles inventory to } \\
\text { show different ways of expression; We } \\
\text { are blends of various cultures }\end{array}$ & $\begin{array}{l}\text { Completion of communication } \\
\text { value orientation assessment and } \\
\text { cross-cultural biography }\end{array}$ & 45 min. \\
\hline $\begin{array}{l}\text { Identify differences within } \\
\text { their group }\end{array}$ & Are groups diverse & $\begin{array}{l}\text { Brainstorm the following question: } \\
\text { how has the diversity within our group } \\
\text { impacted our work }\end{array}$ & $\begin{array}{l}\text { Group brainstorming and } \\
\text { reporting out to the whole group }\end{array}$ & 45 min. \\
\hline Work as a group & $\begin{array}{l}\text { Collaborative group } \\
\text { time }\end{array}$ & $\begin{array}{l}\text { Time for groups to work on second } \\
\text { group project. }\end{array}$ & Group work \\
\hline
\end{tabular}

Assignment:

Readings on dealing with differences and the place of conflict in group work.

Evaluation Plan: Analyze the communication exercise, discussions. 


\section{CREATING COLLABORATIVE LEARNING ENVIRONMENTS}

\section{INSTRUCTIONAL PLAN - WEEK EIGHT \\ Making it Fun}

Learning Objectives:

\begin{tabular}{l|l|l|l|l}
\hline $\begin{array}{c}\text { Participants will be } \\
\text { able to. }\end{array}$ & Content Heading & \multicolumn{1}{c|}{ Key Points } & Instructional Techniques & Time \\
\hline $\begin{array}{l}\text { Identify ways to create a } \\
\text { safe environment }\end{array}$ & $\begin{array}{l}\text { Trust and safety are } \\
\text { musts }\end{array}$ & $\begin{array}{l}\text { Trust and safety reduce barriers created } \\
\text { by conflict } \\
\text { differences, encourage communication }\end{array}$ & Mini-lecture and group discussion & 30 min. \\
\hline $\begin{array}{l}\text { Discuss one approach to } \\
\text { effectively interacting with } \\
\text { among differences }\end{array}$ & Confronting differences & $\begin{array}{l}\text { There are techniques for addressing } \\
\text { problems which occur because of } \\
\text { differences. DUE (from Lieberman) is } \\
\text { one. }\end{array}$ & $\begin{array}{l}\text { Mini-lecture with group } \\
\text { discussion }\end{array}$ & 30 min. \\
\hline $\begin{array}{l}\text { Understand the } \\
\text { contribution of fun to } \\
\text { success in the group }\end{array}$ & Adding fun & $\begin{array}{l}\text { When groups have fun conflicts } \\
\text { accomplished }\end{array}$ & $\begin{array}{l}\text { Mini-lecture interspersed with } \\
\text { silliness }\end{array}$ & 30 min. \\
\hline $\begin{array}{l}\text { Apply the techniques for } \\
\text { dealing with differences }\end{array}$ & Practice clarifying \\
communication & $\begin{array}{l}\text { Critical to address conflicts or } \\
\text { differences but just as critical to } \\
\text { encourage all the voices }\end{array}$ & $\begin{array}{l}\text { Group exercise observed and } \\
\text { critiqued by a second group; then } \\
\text { switched }\end{array}$ & 40 min. \\
\hline Work as a group & Group work & Groups work on projects & Group Work \\
\hline
\end{tabular}

Assignment:

Reminder that third reflection paper is due next session. Readings on the collaborative process.

Evaluation Plan: Analysis on group exercise applying clarifying communications. 


\section{CREATING COLLABORATIVE LEARNING ENVIRONMENTS}

Learning Objectives:

\section{INSTRUCTIONAL PLAN - WEEK NINE \\ Wrapping it Up}

\begin{tabular}{|c|c|c|c|c|}
\hline $\begin{array}{l}\text { Participants will be } \\
\text { able to.. }\end{array}$ & Content Heading & Key Points & Instructional Techniques & Time \\
\hline $\begin{array}{l}\text { Recall what they have } \\
\text { learned }\end{array}$ & Piecing it together & $\begin{array}{l}\text { All the elements woven together can } \\
\text { lead to a productive collaborative } \\
\text { experience }\end{array}$ & $\begin{array}{l}\text { Whole group discussion around } \\
\text { prior sessions }\end{array}$ & $30 \mathrm{~min}$. \\
\hline $\begin{array}{l}\text { Specify ways to insure that } \\
\text { all members have a voice }\end{array}$ & Giving everyone a voice & $\begin{array}{l}\text { Some students are naturally reticent but } \\
\text { it is important to insure they are able to } \\
\text { contribute }\end{array}$ & $\begin{array}{l}\text { Group brainstorming and } \\
\text { reporting out to the whole group }\end{array}$ & $30 \mathrm{~min}$. \\
\hline $\begin{array}{l}\text { Appreciate the importance } \\
\text { of the process }\end{array}$ & $\begin{array}{l}\text { The results can be } \\
\text { greater than the sum of } \\
\text { the parts }\end{array}$ & $\begin{array}{l}\text { In collaboration in which all voices are } \\
\text { heard and commitment to the project } \\
\text { are high, results are great }\end{array}$ & Mini-lecture and group discussion & $30 \mathrm{~min}$. \\
\hline $\begin{array}{l}\text { Understand requirements } \\
\text { for final paper }\end{array}$ & Final individual paper & $\begin{array}{l}\text { The paper is to be an adaptation of a } \\
\text { course to the collaborative learning } \\
\text { approach. }\end{array}$ & Discussion, question and answer & $15 \mathrm{~min}$ \\
\hline $\begin{array}{l}\text { Know when the group's } \\
\text { presentation will be made }\end{array}$ & $\begin{array}{l}\text { Lottery for group } \\
\text { presentations }\end{array}$ & $\begin{array}{l}\text { Determination of which group presents } \\
\text { in which order. }\end{array}$ & Group discussion and decision & $15 \mathrm{~min}$. \\
\hline Add fun to collaboration & What can be fun? & $\begin{array}{l}\text { Design of the final class session around } \\
\text { the presentations }\end{array}$ & Group discussion & $30 \mathrm{~min}$. \\
\hline
\end{tabular}

Assignment: Third reflection paper due. Final paper due next session. Group project presentations next session.

Evaluation: $\quad$ Consideration of questions posed. 


\section{CREATING COLLABORATIVE LEARNING ENVIRONMENTS}

\section{INSTRUCTIONAL PLAN - WEEK TEN \\ Group Project Presentations}

Learning Objectives:

\begin{tabular}{l|l|l|l|l}
\hline $\begin{array}{c}\text { Participants will be } \\
\text { able to.. }\end{array}$ & Content Heading & \multicolumn{1}{|c|}{ Key Points } & Instructional Techniques & Time \\
\hline $\begin{array}{l}\text { Observe group } \\
\text { presentations }\end{array}$ & $\begin{array}{l}\text { Presentations of } \\
\text { group projects }\end{array}$ & $\begin{array}{l}\text { Do the projects require } \\
\text { collaboration? Do they meet the } \\
\text { criteria? }\end{array}$ & $\begin{array}{l}\text { Presentation by groups } \\
\text { followed by questions from } \\
\text { the whole group }\end{array}$ & $2 \mathrm{hr}$. \\
\hline Make sure its fun! & $\begin{array}{l}\text { Celebrate the } \\
\text { course }\end{array}$ & $\begin{array}{l}\text { Conversation, fun, food and } \\
\text { intensity contribute to building } \\
\text { good collaborative groups }\end{array}$ & Group celebration & $20 \mathrm{~min}$. \\
\hline $\begin{array}{l}\text { Formulate and present } \\
\text { questions }\end{array}$ & $\begin{array}{l}\text { Resolve } \\
\text { unanswered issues }\end{array}$ & $\begin{array}{l}\text { Insure that participants have an } \\
\text { opportunity to discuss points of } \\
\text { misunderstanding }\end{array}$ & $\begin{array}{l}\text { Group discussion, question } \\
\text { and answer }\end{array}$ & $10 \mathrm{~min}$. \\
\hline
\end{tabular}

Evaluation:

Analysis of group projects and individual papers. 